
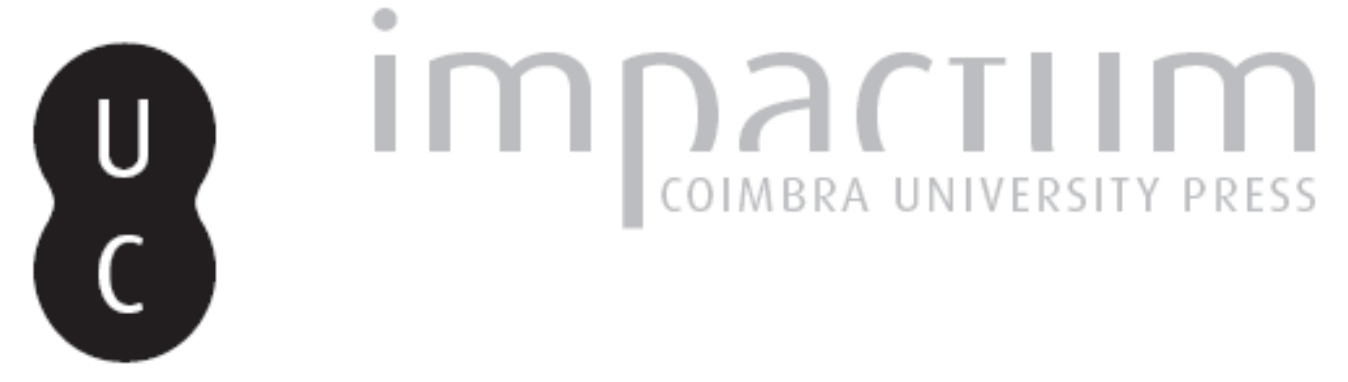

\title{
Paisagens protegidas e incêndios florestais em Brasília: produção voluntária de informações geográficas e sistema de alerta
}
Autor(es):
Tavares, Maria de Fátima Duarte; Nakagomi, Bruno; Soares, Vânia;
Botega, Leonardo Castro; Neris, Vânia Paula de Almeida

Publicado por: Imprensa da Universidade de Coimbra

URL

persistente:

URl:http://hdl.handle.net/10316.2/46129

DOI:

DOI:https://doi.org/10.14195/1647-7723_26-1_5

\section{Accessed : $\quad$ 26-Apr-2023 07:11:46}

A navegação consulta e descarregamento dos títulos inseridos nas Bibliotecas Digitais UC Digitalis, UC Pombalina e UC Impactum, pressupõem a aceitação plena e sem reservas dos Termos e Condições de Uso destas Bibliotecas Digitais, disponíveis em https://digitalis.uc.pt/pt-pt/termos.

Conforme exposto nos referidos Termos e Condições de Uso, o descarregamento de títulos de acesso restrito requer uma licença válida de autorização devendo o utilizador aceder ao(s) documento(s) a partir de um endereço de IP da instituição detentora da supramencionada licença.

Ao utilizador é apenas permitido o descarregamento para uso pessoal, pelo que o emprego do(s) título(s) descarregado(s) para outro fim, designadamente comercial, carece de autorização do respetivo autor ou editor da obra.

Na medida em que todas as obras da UC Digitalis se encontram protegidas pelo Código do Direito de Autor e Direitos Conexos e demais legislação aplicável, toda a cópia, parcial ou total, deste documento, nos casos em que é legalmente admitida, deverá conter ou fazer-se acompanhar por este aviso.

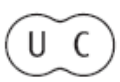




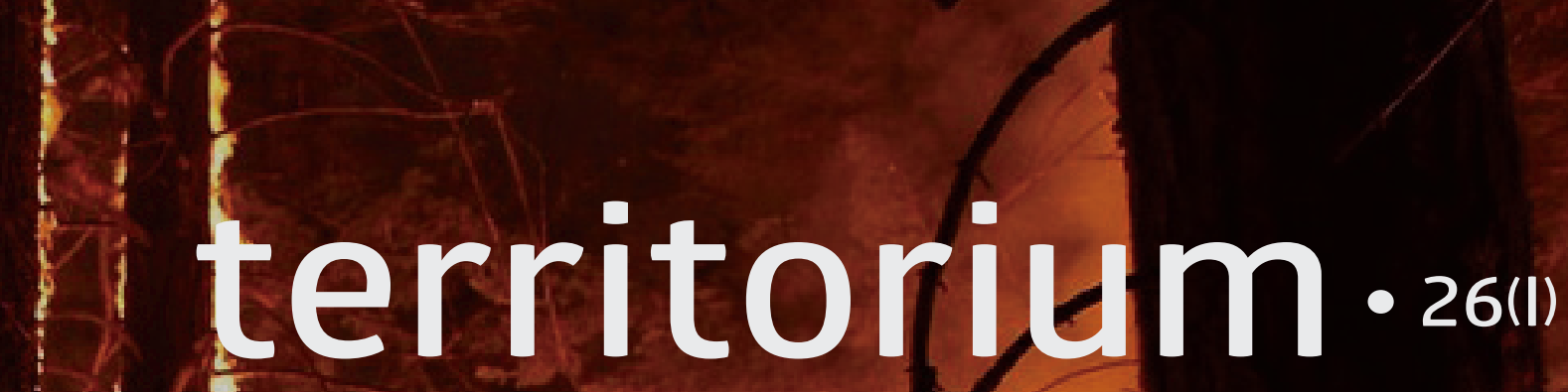

1 REVISTA Internacional de RIsCos I International JOURNAL OF RISKS
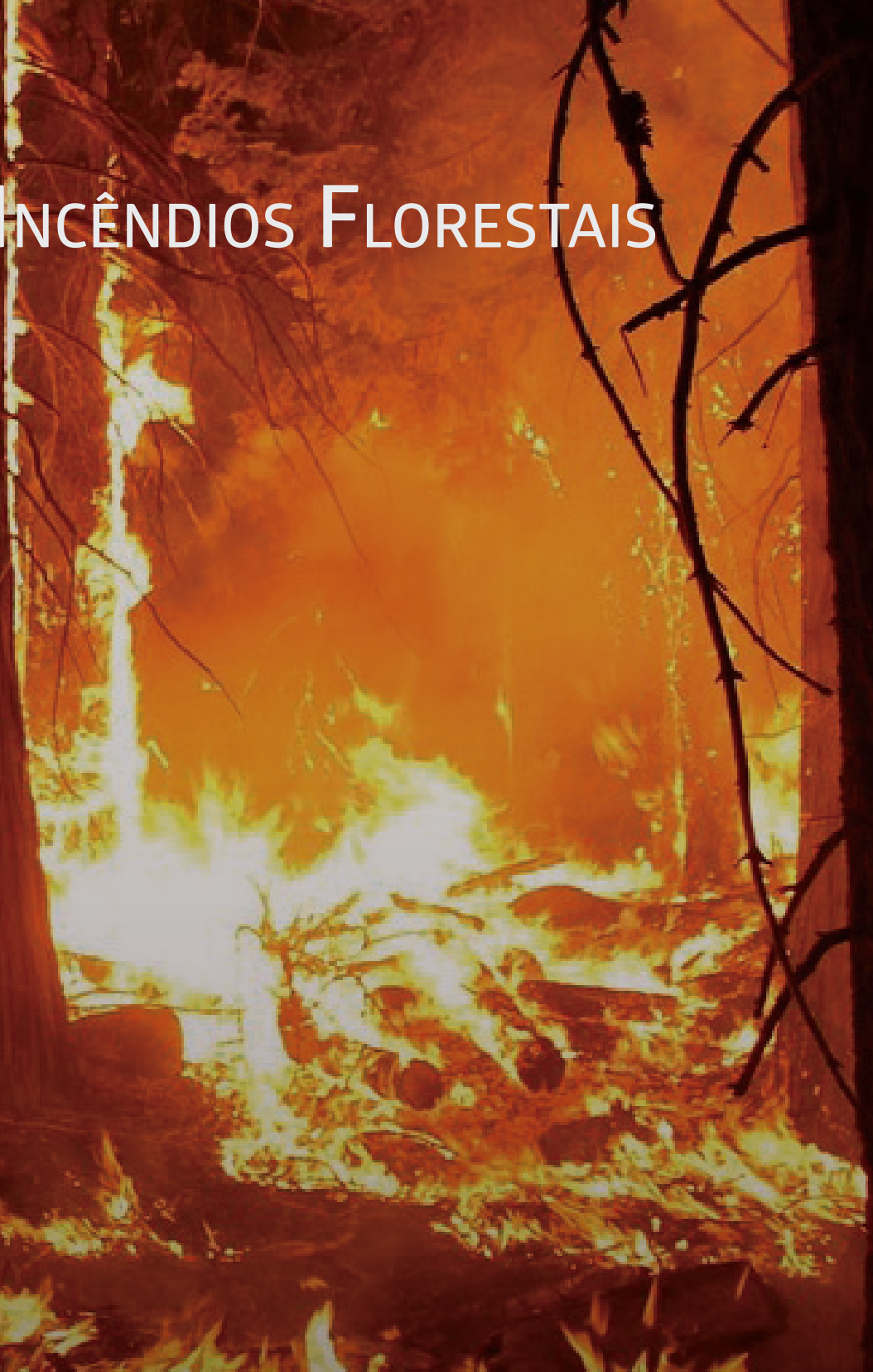

sec

Imprensa da Universidade de Coimbra Associação Portuguesa de Riscos, Prevenção e Segurança 


\section{PAISAGENS PROTEGIDAS E INCÊNDIOS FLORESTAIS EM BRASÍLIA: PRODUÇÃO VOLUNTÁRIA DE INFORMAÇÕES GEOGRÁFICAS E SISTEMA DE ALERTA* \\ PROTECTED LANDSCAPES AND FOREST FIRES IN BRASÍLIA: VOLUNTARY PRODUCTION OF GEOGRAPHIC INFORMATION AND WARNING SYSTEM}

Maria de Fátima Duarte Tavares Instituto Brasileiro de Informação em Ciência e Tecnologia (Brasil) ORCID 0000-0002-6764-8464 fatimatavares@ibict.br

Bruno Nakagomi Instituto Brasileiro de Informação em Ciência e Tecnologia (Brasil) ORCID 0000-0002-7155-0646 brunonakagomi@ibict.br

Vânia Soares

Jardim Botânico de Brasília (Brasil) 0000-0002-3630-2268 vaniasoares.jbb@gmail.com

Leonardo Castro Botega

Faculdade de Filosofia e Ciência, Ciência da Informação Universidade Estadual Paulista "Júlio de Mesquita Filho (Brasil) ORCID 0000-0003-1495-5935 leonardo.botega@unesp.br

Vânia Paula de Almeida Neris

Departamento de Computação Universidade Federal de São Carlos (Brasil) 0000-0002-0858-486X vania@dc.ufscar.br

\section{RESUMO}

As áreas protegidas do Cerrado, em Brasília, estão sendo progressivamente afetadas pela urbanização e por um quadro de recorrências de incêndios florestais. 0 estudo de caso da Estação Ecológica do Jardim Botânico de Brasília apresenta essas condições, que traduzem a relevância da participação da sociedade local nas dinâmicas de gestão de situações de risco. Neste âmbito, propõe-se um sistema de alerta para gestão da informação em processos decisórios e para estimular o reconhecimento social do problema por meio da produção voluntária de informações geográficas.

Palavras-chave: Cerrado, riscos, processos decisórios, tecnologias móveis, urbanização.

\section{ABSTRACT}

Protected Cerrado [savanna] areas in Brasília have been increasingly affected by urbanization and recurrent forest fires. This case study of the Brasília Botanical Garden Ecological Station [EEJBB] describes these factors, which elucidate the importance of local community participation in the dynamics of risk situation management. In this context, we propose a warning system to manage the information generated in decision-making processes and incentivize society to recognize the problem through the voluntary production of geographic information.

Keywords: Cerrado, risk, decision-making processes, mobile technologies, urbanization.

\footnotetext{
* O texto deste artigo corresponde a uma comunicação apresentada no IV Congresso Internacional de Riscos, tendo sido submetido em 07-08-2017, sujeito a revisão por pares a 22-09-2017 e aceite para publicação em 12-05-2018. Este artigo é parte integrante da Revista Territorium, n. ${ }^{\circ} 26$ (I), 2019, ${ }^{\circ}$ RIscos, ISSN: 0872-8941.
} 


\section{Introdução}

As áreas protegidas do Cerrado no território do Distrito Federal (DF), na região central do Brasil, estão sendo progressivamente afetadas pela urbanização (fig. 1). As mudanças no ordenamento territorial estão, também, associadas à ocorrência de incêndios florestais, que atingem, com frequência, as principais unidades de conservação criadas após a fundação de Brasília (DF, 2016 a; DF, 2011). Com efeito, a análise inicial dessas condições, a extensão das áreas atingidas e o quadro de recorrências justificam a estratégia de ampliar a participação da sociedade local nas dinâmicas de gestão de situações de risco (fig. 2).

De forma complementar aos programas locais de prevenção e de sistemas nacionais de monitoramento de queimadas, este estudo, multidisciplinar e multi-institucional, propõe um sistema de alerta para estruturar a gestão da informação em processos decisórios e estimular o reconhecimento social do problema por meio da produção voluntária de informações geográficas. A aplicação experimental do sistema de alerta vai envolver o território do Jardim Botânico de Brasília (JBB) e sua Estação Ecológica (EEJBB), que integram um mosaico de unidades de conservação, com 10 mil hectares de Cerrado, em que estão representadas praticamente todas as fitofisionomias características do bioma, constituindo a área núcleo de vida silvestre da Reserva da Biosfera do Cerrado, em classificação da UNESCO de 1982 (fig 3).

O Jardim Botânico de Brasília, como instituição gestora da EEJBB, participa do Programa de Combate e Prevenção a Incêndios Florestais do Distrito Federal e desenvolve atividades de prevenção de incêndios florestais buscando medidas para a eliminação de suas causas, bem como, a redução dos riscos de propagação do fogo, em cooperação com demais unidades (DF, 2011; DF, 2016 b). Os incêndios que ocorrem no JBB e sua Estação Ecológica durante a estação seca, na maioria das vezes, são provenientes de ações antrópicas oriundas de quadras residenciais internas do Lago Sul, a noroeste, da área da Base Aérea da Aeronáutica e do Setor de Mansões Parque Way a oeste e da rodovia DF-001 a leste, que fazem limite com a Estação Ecológica, conforme será detalhado em próximos itens. Nos últimos 15 anos a área sofreu, pelo menos, dois grandes incêndios florestais, em 2005 e 2011, que queimaram, respectivamente, cerca de $70 \%$ e 50 \% da área protegida (S. Correa, 2007; DF, 2011).

$A$ área de estudo foi pré-determinada por uma poligonal de $3 \mathrm{~km}$ projetados a partir dos limites do Jardim Botânico de Brasília e de sua Estação Ecológica, esta última unidade de proteção integral criada em 1992, tendo em vista caracterizar as relações da ocupação territorial e identificar áreas de maior vulnerabilidade à recorrência de incêndios florestais. As duas principais delimitações ou interfaces da área são, de um lado, a rodovia DF001 e, de outro, o Ribeirão do Gama, que constituem elementos de referência espacial e paisagística (fig. 3).

\section{O Cerrado e Incêndios Florestais}

O Cerrado, classificado em geral como bioma semelhante às savanas, abriga composições paisagísticas diversificadas, que Ab'Saber propunha traduzir como um dos domínios espaciais morfoclimáticos e fitogeográficos do Brasil. Os traços paisagísticos e ecológicos integrados desse domínio configuram um complexo que marca uma área core de forma extensa e contínua (A. Ab’Saber, 2003, p.11). Segundo Ab'Saber, esse domínio, que prevalece na região do Planalto Central, é um dos mais arcaicos do território brasileiro e é dependente, em sua caracterização, dos solos, do quadro climático e hidrológico próprios (A. Ab’Saber, 2003, p.31). As dificuldades de definição e de classificação das paisagens do Cerrado apontadas por Eiten e Ab'Saber (A. Ab'Saber, 2003; G. Eiten, 1977) foram colocadas como problema nos anos 60 e 70 do século passado, em que a dinâmica de ocupação desse território era distinta da atual, com a expansão da rede urbana após Brasília e a transformação decorrente de práticas intensivas de produção agrícola em larga escala (A. Ab’Saber, 2003, p. 35 e p. 43; ). Note-se que os estudos sistemáticos e continuados sobre a estrutura das fitofisionomias do Cerrado, sua fauna e flora, são relativamente recentes e ganham amplitude de forma paralela ao processo acelerado de ocupação do interior do centro-oeste do país, notadamente, após os anos 70 do século XX. Conforme Walter, no debate sobre a equivalência conceitual ou não dos cerrados à savana, pesou na atualidade a aceitação da predominância das semelhanças e não da diversidade, que era enfatizada por Eiten (B. Walter, 2006).

Para efeito deste trabalho, importa considerar os traços dominantes de caracterização do Cerrado: multiplicidade de formações de paisagem, cuja vegetação apresenta uma capacidade adaptativa de longa duração ao fogo; solos muito pobres; e clima tropical (semi-úmido e quente), em que prevalecem prolongados períodos bem definidos de seca no inverno e chuvoso no verão (IBAMA, 2010, p. 23; M. Medeiros, H. Miranda, 2005, p. 493; B. Walter, 2006, p. 29). As fitofisionomias do Cerrado, entendido como bioma, podem ser agrupadas em conjuntos de campos, florestas e savanas, que são afetadas de forma diferenciada pelo regime de fogo, ou seja, pela frequência e quadro climático de ocorrência (B. Walter, 2006). Note-se que as queimadas naturais que ocorrem no Cerrado são relativamente frequentes, principalmente, na transição do período seca-chuva. No geral, as queimadas por causas naturais, decorrentes de raios, não atingem grandes áreas, uma vez que a chuva posterior impede a propagação de incêndios de maior magnitude. 


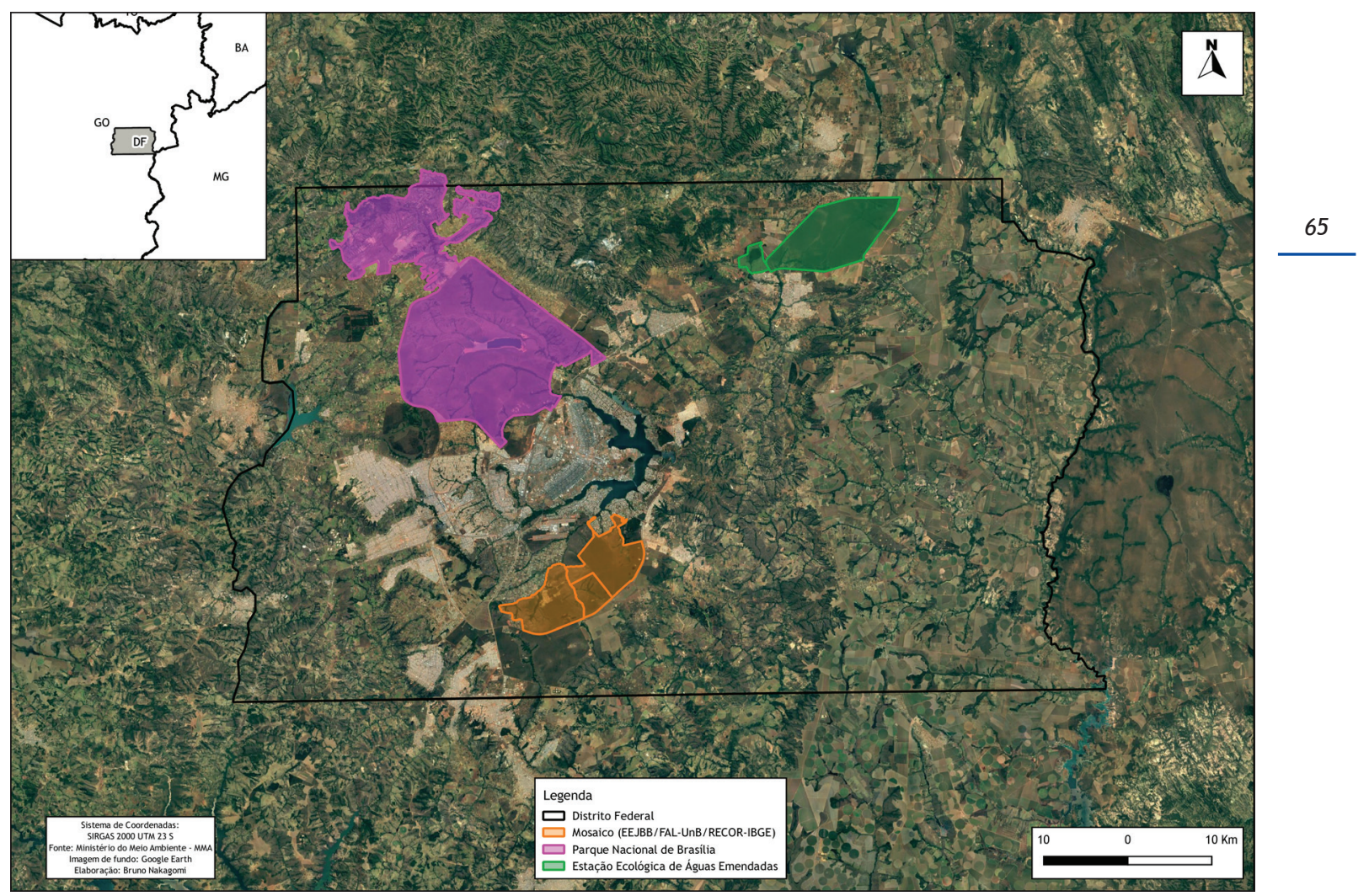

Fig. 1 - Áreas protegidas de conservação integral do DF.

Fig. 1 - Protected areas of integral conservation of the Federal District [DF].

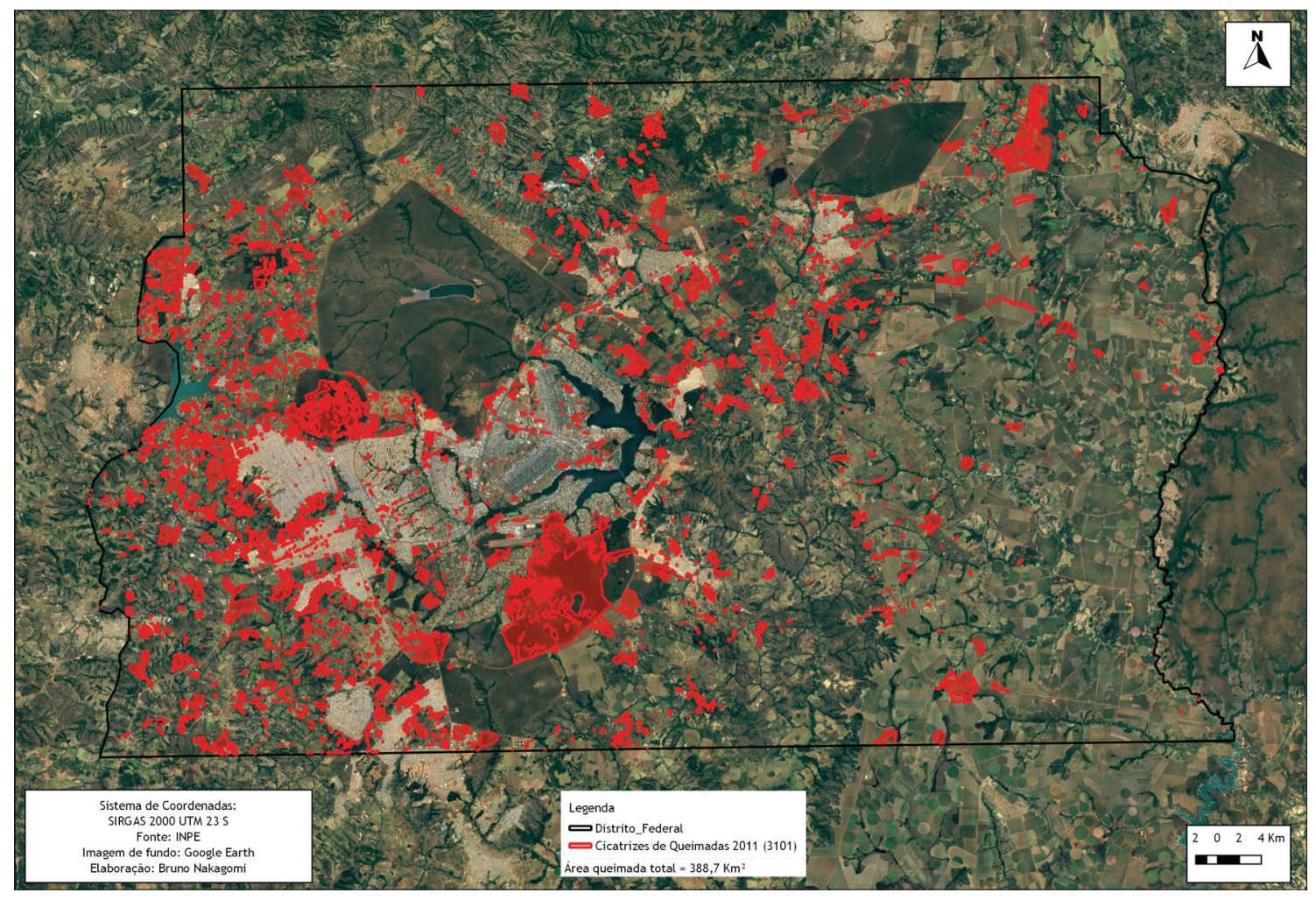

Fig. 2 - Cicatrizes de queimada no DF - 2011.

Fig. 2 - Burn scars within the DF - 2011. 


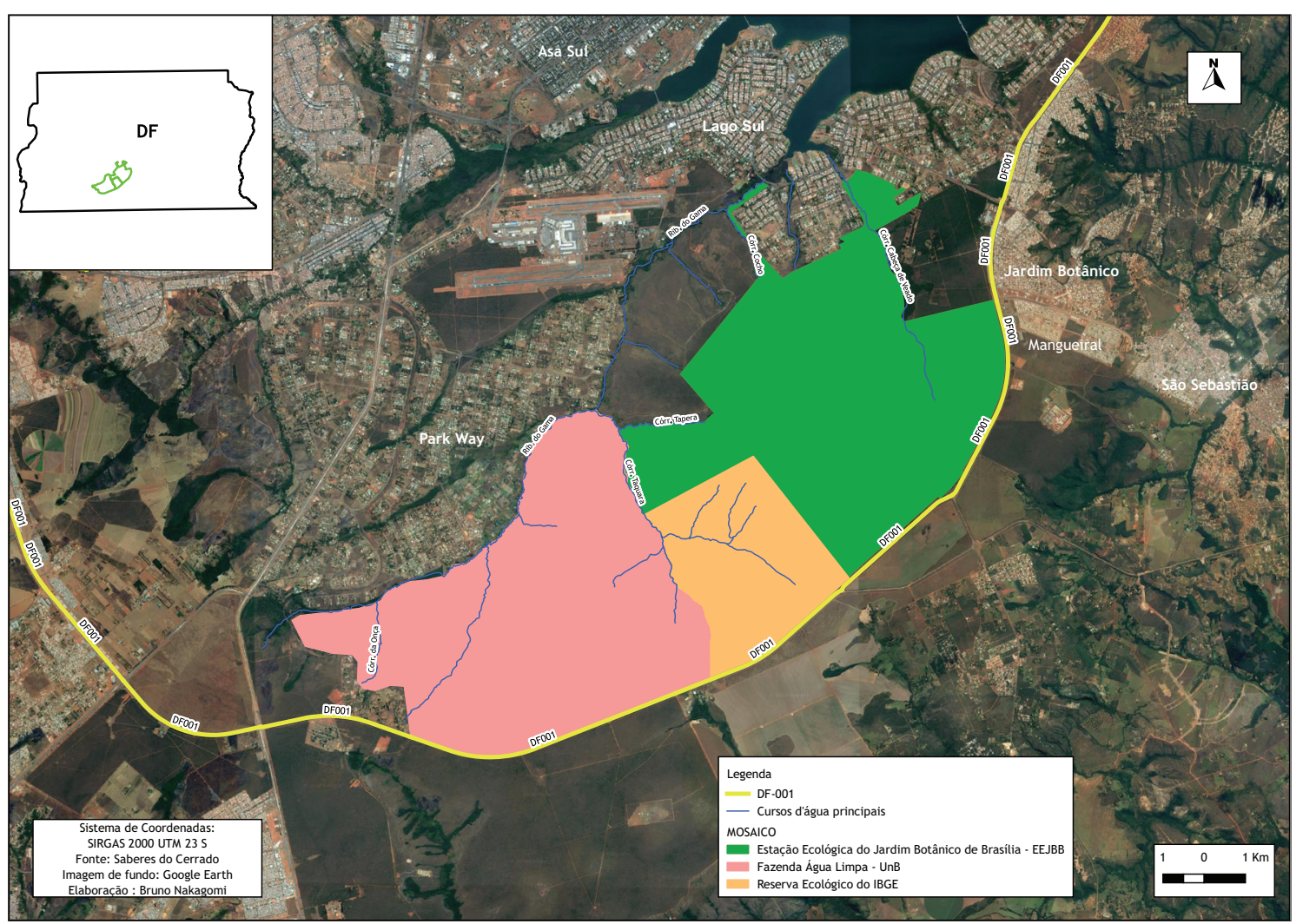

Fig. 3 - Mosaico de áreas protegidas.

Fig. 3 - Mosaic of protected areas.

\section{Metodologia}

A construção de requisitos do sistema de alerta depende do reconhecimento das condições de ocorrência de incêndios florestais, dos processos de gestão da informação e das dinâmicas de instâncias decisórias no controle de eventos críticos. Contudo a ausência de séries históricas estruturadas e disponíveis de dados locais de incêndios florestais, em sistemas de informação do DF, levou a considerar a relevância da prévia análise urbana e ambiental e dos demais fatores associados ao quadro de ocorrências.

A metodologia aplicada para identificar os territórios de risco abrange o levantamento de dados e análise do processo de ocupação urbana e sua transformação histórica, desde a fundação de Brasília.

A primeira etapa consistiu na análise do impacto da urbanização sobre a área protegida, em termos de densidade ocupacional, traços populacionais e tendência ao insulamento. Esses dados, baseados em fontes imagéticas, cartográficas e estatísticas de população, foram estruturados em um Sistema de Informações Geográficas (SIG).

$\mathrm{Na}$ segunda fase, considerou-se o período 2010-2016, pois, em Brasília, o ano de 2011 foi o de maior criticidade em incêndios florestais recentes. Para este período, foram levantados e agrupados os dados de focos de calor, obtidos a partir de satélites, constantes na base de queimadas do Instituto Nacional de Pesquisas Espaciais (INPE). O mapeamento resultante permitiu observar o arco do fogo da unidade de conservação e indicar as relações prioritárias para a elaboração de requisitos do sistema, que envolvem os fatores físico-geográficos, os traços populacionais e os efeitos das dinâmicas e condições meteorológicas.

A partir deste estudo de caso, a escala de análise será, posteriormente, ampliada para atingir outras unidades de conservação do DF, tendo em conta situações diferenciadas e aperfeiçoamento dos requisitos do sistema, em termos de sua complexidade e relevância.

Este sistema gestor, que se encontra em fase de pesquisa e desenvolvimento informático, poderá ser adequado a outros contextos e aplicado a outras áreas geográficas, com a integração de dados diversos: as notificações voluntárias de ocorrência de incêndios florestais por meio de aplicativos em dispositivos móveis, os componentes inerentes à logística de prevenção e combate do corpo de bombeiros, o mapeamento das zonas de maior vulnerabilidade, decorrentes tanto de condições ambientais quanto dos contingentes populacionais, além da atualização de dados dinâmicos, derivados das condições meteorológicas. 
As atividades foram realizadas em quatro etapas interrelacionadas: caracterização espacial e paisagística da área como etapa de identificação de territórios de risco; análise de dados associados a situação crítica de incêndios florestais; análise da contribuição voluntária de dados geográficos em aplicações com utilização de dispositivos móveis; e metodologia inerente ao desenvolvimento computacional do sistema com fusão de dados, tendo em vista a gestão de situações críticas. A investigação multidisciplinar obedeceu aos seguintes objetivos:

- Objetivos gerais

1. Caracterizar ocupação de área de estudo e sua vinculação com situações críticas derivadas de IFS;

2. Caracterizar recursos de aplicações em dispositivos móveis e metodologia de analise de dados para estruturação do sistema de alerta;

- Objetivos específicos

3. Identificar relações intraurbanas associadas à recorrência de IFs;

4. Identificar sistemas de informação e disponibilidade de dados associados a IFs;

5. Identificar períodos críticos e dimensão espacial das recorrências;

6. Identificar paisagens afetadas pelos IFs;

\section{Materiais}

O Cerrado era dominante na região do DF até 1955, marco temporal inicial da implantação de Brasília, inaugurada em 1960. Note-se que o predomínio do bioma, com suas variações paisagísticas, foi mantido apesar do processo de ocupação colonial que desde o século XVIII incluiu núcleos urbanos e práticas extensivas de agricultura e pecuária. Na atualidade, 58,2 \% do território do DF já perdeu a vegetação nativa e as áreas remanescentes tendem à fragmentação, que decorre em grande medida da urbanização (DF, 2015).

Nesse quadro, o problema dos incêndios florestais (IF), em suas múltiplas dimensões, humana e ambiental, assume proporções de maior intensidade e risco, apesar de políticas e planos de prevenção e combate às situações críticas, na medida em que as áreas urbanizadas se aproximam de Unidades de Conservação (UC) e das Áreas de Proteção Permanente (APP), que visam à proteção do bioma e de seus recursos hídricos. A transformação acelerada das paisagens do Cerrado traz um componente de desafio à construção de políticas de ordenamento territorial e do envolvimento da sociedade local nas práticas de prevenção a incêndios florestais. Por outro lado, a análise urbana e o recorte espacial deste estudo de caso advêm da necessidade de se dar foco às relações que prevalecem nestas zonas de interface urbana, associadas às condições de preservação de paisagens naturais.

\section{Caracterização da ocupação da área de estudo}

$A$ área de estudo é constituída pelo Jardim Botânico de Brasília (JBB) e sua Estação Ecológica (EEJBB), que detêm aproximadamente 5.000 ha, e uma zona de envolvência de 3 km, denominada de Área de Influência Direta (AID), que está situada em meio aos bairros do Lago Sul, Jardim Botânico e São Sebastião, respectivamente alinhados de noroeste a leste. Esta configuração permite observar processos diversos de ocupação urbana, todos sustentados no domínio da habitação individual, mas caracterizados por elevada distinção socioeconômica (fig. 3).

$\mathrm{Na}$ vertente sul situam-se em sequência outras áreas protegidas, Reserva Ecológica do Roncador, administrada pelo Instituto Brasileiro de Geografia e Estatística (IBGE) e Área de Relevante Interesse Ambiental Capetinga/Taquara, gerida pela Fazenda Agua Limpa - Universidade de Brasília. E, mais a oeste, o Setor de Mansões Park Way (fig. 3).

A estrutura urbana atual que define a AID se superpôs a uma ocupação anterior e secular de fazendas, organizadas em grandes glebas, que deixaram poucos vestígios materiais. Dois estágios de ocupação após Brasília podem ser identificados, considerando as categorias de alta, média e baixa densidade (fig. 4).

Nos anos 60, o Lago Sul teve sua infraestrutura implantada e parcelamento criados por normativas, com traços de ordenamento que privilegiaram a proximidade da orla do lago artificial, frontal ao Plano Piloto, e com média densidade de ocupação. Por outro lado, a implantação urbanística do Lago Sul respeitou um relativo distanciamento das matas ciliares e de estuários de rios ou de pequenos cursos d'agua, que passaram a desaguar no Lago Paranoá, recriando assim o cenário paisagístico. Já o Park Way, setor inicialmente suburbano, hoje dominado por condomínios, foi dividido nos anos 60 em parcelas de 2 ha, envolvidas por extensas áreas livres. Apesar da reocupação, está ainda enquadrado na classificação de baixa densidade.

De meados dos anos 80 em diante, nas áreas rurais situadas na vertente norte e leste, separadas da área da EEJBB pela rodovia DF001 e no entorno da bacia do Rio São Bartolomeu adjacente, são gradativamente disseminadas ocupações de caráter irregular, em condomínios fechados de pequenas parcelas e intensificada impermeabilização do solo, contribuindo para a redução de áreas de recarga de aquíferos e comprometimento de nascentes. Na conjuntura atual, essa zona, denominada de Jardim Botânico, enquadrase na classificação de alta densidade. O setor de São Sebastião, a leste, com população de baixa renda, é outra área de alta densidade. A ocupação teve origem em antigo núcleo rural, que foi posteriormente adensado pela presença de olarias envolvidas com a construção de 
Brasília. Esta área, situada no trecho de um corredor ecológico, passou por um processo acelerado de urbanização, que inclui o conjunto Mangueiral.

A tendência ao insulamento da EEJBB já foi demonstrada em análise espaço - temporal, considerado o período de1964 a 2013 (M. Tavares, B. Nakagomi, 2016 ). Esse traço constitutivo das relações espaciais locais não só permite reconhecer um quadro de atenção ao papel da Unidade de Conservação, constituída pela EEJBB, mas é também uma das faces do problema da recorrência de incêndios florestais na área de estudo.

\section{Incêndios Florestais no DF e Serviços de Informação}

O problema de incêndios florestais, decorrentes da ação humana, afeta todos os biomas e é um dos principais fatores, associado ao desmatamento e à urbanização, de perda progressiva da biodiversidade no Brasil. Embora estejam em operação sistemas de monitoramento e controle de âmbito nacional e estejam em vigor planos de ação específicos, é determinante o papel dos agentes locais, considerando a gestão de situações críticas e a capacidade de estabelecer processos sistemáticos de prevenção, monitoramento e controle para neutralizar / minimizar os impactos de focos de incêndio, em especial, sobre áreas protegidas em situação urbana.
Note-se que a valorização das instâncias locais, em acordos de âmbito internacional, para a prevenção de situações de desastres está sendo enfatizada. O Marco de Sendai, de 2015, do qual o Brasil é signatário, em substituição ao Marco de Ação de Hyogo, que já contemplava a questão da resiliência das cidades aos processos de enfrentamento e adequação a situações críticas, traduz esse enfoque ao reconhecer que deve ser prioritária a atenção local.

Verifica-se que os sistemas de informação existentes (nacionais) identificam situações pós-evento e em conformidade hierárquica institucional da Política Nacional de Proteção e Defesa Civil (PNPDC). A verificação de 2 registros do DF no Sistema Integrado de Informações - S2ID, do Ministério da Integração Nacional, que atende à PNPDC, para o período de 1990 a 2015, confirma os dados do DF já apresentados no Atlas Brasileiro de Desastres Naturais, de 2 incêndios florestais nos anos de 2007 e 2010 (CEPED/ UFSC, 2012).

Aqui se depreende que esse sistema nacional somente se reporta a níveis mais elevados de intensidade e à demanda por apoio federal, financeiro e de recursos humanos, na contenção ou resposta aos eventos notificados (M. Kobiyama, 2006).

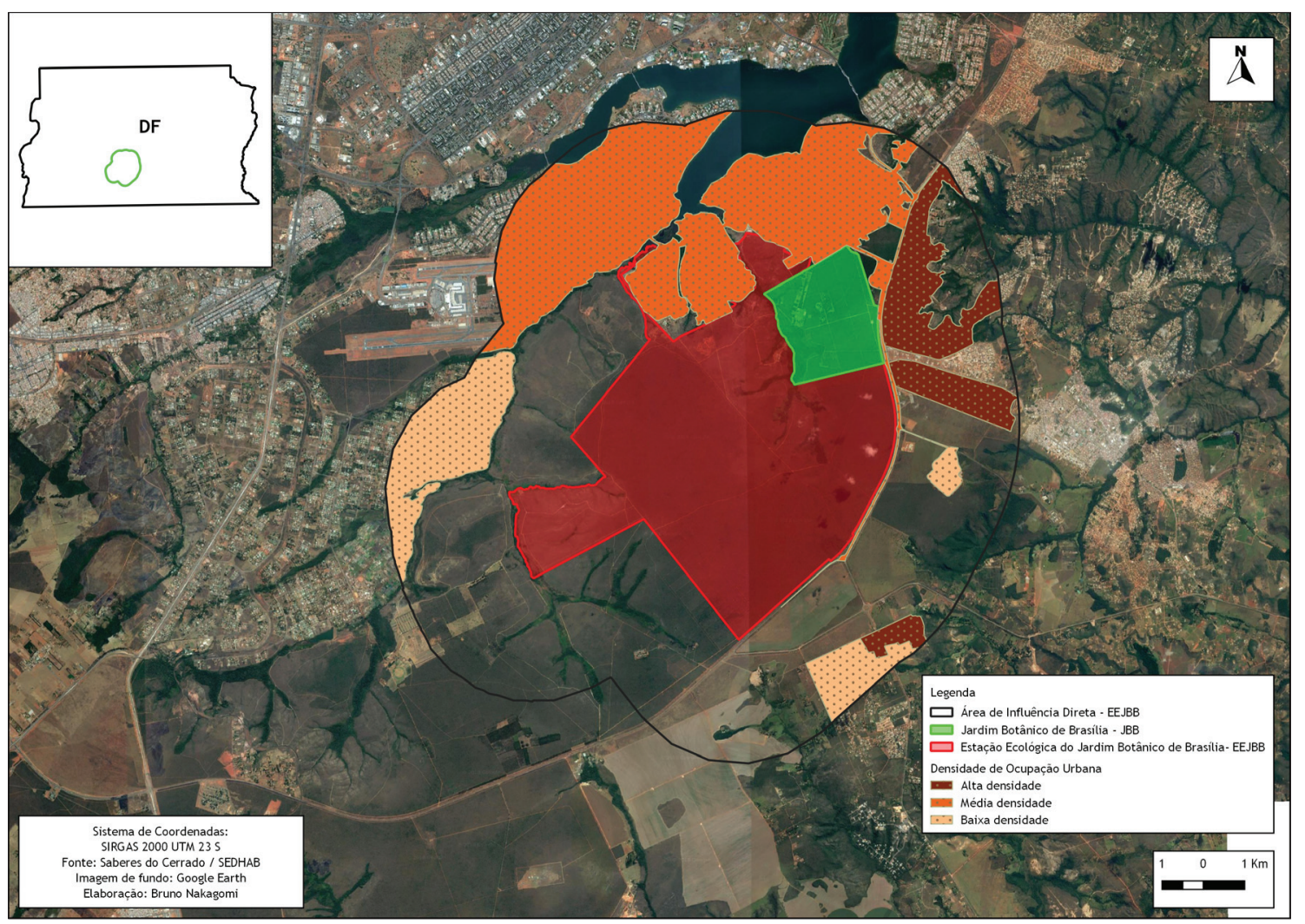

Fig. 4 - Densidade de ocupação urbana - 2013.

Fig. 4 - Density of urban occupation - 2013. 
Outros 4 registros sobre incêndios florestais no DF estão disponíveis no Sistema Nacional de Informações sobre Fogo (SISFOGO), do Centro Nacional de Prevenção e Combate aos Incêndios Florestais - PREVFOGO / Ministério do Meio Ambiente (MMA). A consulta abrangeu o período de 2008 a 2016, no assunto área queimada do DF, identificando ocorrências nos anos de 2008, 2009, 2010 e 2011 e respectiva mensuração de áreas: 32, 93 ha; 0,13 ha; 1988,73 ha e 2168,72 ha. Embora os registros sejam escassos, a sequência confirma o crescimento da extensão de áreas atingidas (IBAMA, 2016).

A situação do DF quanto à recorrência anual dos incêndios florestais e também quanto a sua intensificação pode ser observada em termos da extensão de áreas queimadas, apesar da existência de política pública local, estruturada no Plano de Prevenção e Combate a Incêndios Florestais, desde 1996, com o Decreto $n^{\circ} 17.431$ e Decreto ${ }^{\circ} 37.549$ (DF, 1996; DF 2016b). O Relatório de Áreas Queimadas em Unidades de Conservação, do Instituto Brasília Ambiental (IBRAM), torna público o problema da dificuldade de monitoramento das áreas protegidas no DF, amplamente afetadas por incêndios florestais (DF, 2016a). O Relatório faz utilização da disponibilidade de dados e imagens do serviço nacional de Base de Queimadas do Instituto Nacional de Pesquisas Espaciais (INPE), porém reconhece que existem dificuldades para o monitoramento do Cerrado por sensoriamento remoto, que também já foram explicitadas em outros estudos (A.Pereira Junior, 2003).

Apesar das limitações quanto ao potencial reconhecimento de número de focos de calor e seus efeitos nas áreas atingidas, a Base de Queimadas (BQ) do INPE, junto aos dados meteorológicos do Instituto Nacional de Meteorologia (INMET), constituem fontes acessíveis de dados e podem contribuir efetivamente para elaboração de políticas públicas no que toca à prevenção de incêndios florestais em uma perspectiva regional e em áreas de fraco monitoramento local. E, no caso do INMET, a qualidade da aferição meteorológica é relativa, pois depende da localização de somente 2 estações automáticas para traçar condições gerais para o DF.

Cumpre, no entanto, observar que o sistema do INPE e suas séries históricas podem ser utilizados para a análise comparativa de condições locais no contexto da área de estudo e da aplicação de produção voluntária de informações geográficas.

O levantamento de dados para o DF, nas séries históricas de 1998 a 2017 da BQ do INPE, indica o ano de 2010 com o maior número de focos de calor detectados, considerando o satélite de referência. Indicação válida também para o bioma Cerrado em sua totalidade (INPE, 2017). Já os pontos coletados para a AID e EEJBB, considerando todos os satélites nos anos de 2010 a 2016, indicam o ano de 2011 como o de maior número de focos de calor.
Por outro lado, o levantamento anual para 2010 e 2011, com todos os satélites, relacionando o DF e unidades de conservação, torna evidente a incidência diferenciada relativa às unidades de conservação integral. Comparando-se três unidades de conservação de grande relevância ecológica para Brasília, a Estação Ecológica de Aguas Emendadas (ESECAE), o Parque Nacional de Brasília (PNB) e a EEJBB, observa-se que prevaleceu para as duas primeiras o ano de 2010 como o de maior número de pontos detectados (INPE, 2017). Para efeito de verificação do ano mais crítico entre 2010 e 2017, segundo os focos de calor da base do INPE, o ano de 2010 seria o mais crítico para o DF e o de 2011 o mais crítico para a área de estudo, conforme dados processados no Sistema de Informações Geográficas (SIG).

A comparação entre número de focos e extensão de áreas queimadas em Unidades de Conservação (UC) e outras áreas protegidas subordinadas ao IBRAM/DF, agência ambiental do DF, apresentados no Relatório de Áreas Queimadas, acima referido, demonstra que a dinâmica dos incêndios florestais é mais complexa do que o registro dos focos de calor é capaz de expor. Note-se que este relatório não contempla dados relativos à Estação Ecológica do JBB e o ao Parque Nacional de Brasília (PNB) por se constituírem em unidades com gestão diferenciada.

No ano de 2010, para efeito comparativo, a ESECAE, que tem área de 9.372,37 ha, teve identificados 8 focos de calor e uma extensão de área queimada de 1.491,71 ha, correspondendo a 15,92 \% do seu território e 65,62 \% do total de 2273,19 ha da área atingida das unidades do IBRAM. Sendo 125 o total de focos de calor identificados para 28 unidades afetadas (DF, 2016).

Em 2011, considerando-se, porém, que foram atingidas 45 unidades, distribuídas no território do DF, e que foram expostos aos incêndios florestais um total de 1862,7 ha, incluindo 130, 75 ha da ESECAE, tende-se a observar que o ano de 2011 está entre os mais críticos para o DF, no período analisado de 2010 a 2017 (DF, 2016).

O Jardim Botânico Brasília e sua Estação Ecológica, no ano de 2011, tiveram uma extensão de área queimada da ordem de 2.500,00 ha, do total de área protegida de aproximadamente de 5.000 ha, segundo o Relatório de Atividades do JBB para o período (DF, 2011). Os dados de cicatrizes do DF, de 2011, extraídos da base do INPE, com total de área queimada superior a $380 \mathrm{~km}^{2}$, representados na fig. 2, demonstram a dispersão das áreas atingidas de menor extensão e a ocorrência em larga escala sobre a área do Mosaico.

$\mathrm{Na}$ utilização dos dados da BQ do INPE não está propriamente em questão a precisão da localização dos focos e sua incapacidade de reconhecimento de focos pouco extensos e de baixa intensidade, como 
outros estudos já acentuaram (A. P. Júnior, 2003). Mas interessa observar o potencial de resposta, em paralelo a outras análises, para as condições espaço-temporais das ocorrências.

Dados da Base de Queimadas do INPE e Incêndios Florestais na Estação Ecológica do Jardim Botânico de Brasília - EEJBB

A análise do quadro de Incêndios Florestais na EEJBB parte dos dados de focos de calor retirados da Base de Queimadas do Instituto Nacional de Pesquisas Espaciais (INPE), considerando a série acumulada no período de 2010 a 2016, que foi objeto de processamento e mapeamento no Sistema de Informação Geográfica (SIG) do Projeto Saberes do Cerrado. Nesse período, foram detectados 354 pontos no interior da área de estudo. A distribuição espacial e temporal desses focos permite reconhecer o que denominamos de arco do fogo associado à EEJBB, assim serão considerados os dados totais e parciais, por período de seca ou chuvoso.

0 ano de 2011 concentra a maioria dos focos, no total de 161. Os pontos detectados nos demais anos ajudam a observar o processo de recorrência. Em 2012 e 2015 nenhum foco foi identificado no interior da Unidade de Conservação (EEJBB). Nos anos 2010, 2013, 2014 e 2016 a proporção de ocorrências internas também é bem inferior às externas à EEJBB, conforme QUADRO I. Observa-se que essa distinção ano a ano permite situar o quadro espacial e temporal dos focos, considerando-se a dinâmica após o incêndio florestal de 2011 (DF, 2011).
A localização de focos indica visualmente a prevalência da relação com a rodovia DF001 e com as áreas de baixa e média densidade de ocupação urbana, anteriormente descritas. Porém, metodologicamente, consideramos circunscrever a análise da recorrência à distribuição de focos de calor por quadrantes, conforme fig. 7, e por períodos de criticidade. 0 objetivo é trabalhar a dimensão quantitativa por áreas de envolvência, mas também associar os registros assim agregados por localização ao seu fluxo temporal. Esses dados, desta forma, serão úteis na comparação com os registros das condições meteorológicas da base de dados históricos (BDMEP) do Instituto Nacional de Meteorologia (INMET) e na análise futura de outros fatores.

A série acumulada de focos de calor no período de 2010 a 2016, por quadrantes e no período de seca (abril- setembro), demonstra que prevalecem quantitativamente os quadrantes 3 e 4 , em relação aos demais, e setembro, é o mês que concentra temporalmente a maioria dos registros, considerando os sete anos em análise. Conforme QuAdros I e II e figs. 5 e 6. O período de seca de abril a setembro foi adotado, embora existam variações anuais, para compatibilizar esta pesquisa com as análises de longo prazo de dados do INMET quanto aos padrões e predominâncias de ventos para o DF, tendo por base a Estação Brasília (código 83377) (INMET, sd). Corrobora também para essa periodização a análise de dados do INPE para o DF com o reconhecimento da redução histórica de focos de calor a partir de outubro (INPE, 2017).

QuADRo I - Focos por ano - período de seca e chuvoso.

TABLE I - Fires per year - dry and rainy season.

\begin{tabular}{|c|c|c|c|c|c|c|c|c|c|c|c|c|c|c|c|c|}
\hline \multirow{2}{*}{ Quadrante } & \multirow{2}{*}{ Zona } & \multicolumn{2}{|c|}{2010} & \multicolumn{2}{|c|}{2011} & \multicolumn{2}{|c|}{2012} & \multicolumn{2}{|c|}{2013} & \multicolumn{2}{|c|}{2014} & \multicolumn{2}{|c|}{2015} & \multicolumn{2}{|c|}{2016} & \multirow{2}{*}{ Total } \\
\hline & & $\mathrm{S}^{*}$ & $\mathrm{CH}^{*}$ & $\mathrm{~S}^{*}$ & $\mathrm{CH}^{*}$ & $S^{*}$ & $\mathrm{CH}^{*}$ & $\mathrm{~S}^{*}$ & $\mathrm{CH}^{*}$ & $\mathrm{~S}^{*}$ & $\mathrm{CH}^{*}$ & $\mathrm{~S}^{*}$ & $\mathrm{CH}^{*}$ & $\mathrm{~S}^{*}$ & $\mathrm{CH}^{*}$ & \\
\hline \multirow{2}{*}{ Q1 } & EEJBBB & 0 & 0 & 12 & 0 & 0 & 0 & 0 & 0 & 5 & 0 & 0 & 0 & 0 & 0 & 17 \\
\hline & AID & 2 & 0 & 20 & 0 & 0 & 0 & 5 & 0 & 27 & 0 & 2 & 1 & 4 & 1 & 62 \\
\hline \multirow{2}{*}{ Q2 } & EEJBBB & 0 & 0 & 17 & 0 & 0 & 0 & 0 & 0 & 3 & 0 & 0 & 0 & 0 & 0 & 20 \\
\hline & AID & 3 & 2 & 6 & 1 & 1 & 0 & 1 & 0 & 3 & 0 & 2 & 6 & 9 & 0 & 34 \\
\hline \multirow{2}{*}{ Q3 } & EEJBBB & 0 & 0 & 11 & 0 & 0 & 0 & 5 & 0 & 3 & 0 & 0 & 0 & 2 & 0 & 19 \\
\hline & AID & 11 & 1 & 20 & 0 & 2 & 0 & 12 & 0 & 11 & 8 & 33 & 1 & 4 & 3 & 108 \\
\hline \multirow{2}{*}{ Q4 } & EEJBBB & 2 & 0 & 8 & 0 & 0 & 0 & 0 & 0 & 2 & 0 & 0 & 0 & 0 & 0 & 12 \\
\hline & AID & 5 & 0 & 66 & 0 & 1 & 0 & 4 & 0 & 2 & 0 & 4 & 0 & 1 & 0 & 83 \\
\hline \multirow{3}{*}{ Total } & EEJBBB & 2 & 0 & 48 & 0 & 0 & 0 & 5 & 0 & 13 & 0 & 0 & 0 & 2 & 0 & 70 \\
\hline & AID & 21 & 3 & 112 & 1 & 4 & 0 & 22 & 0 & 43 & 8 & 41 & 8 & 17 & 4 & 284 \\
\hline & $\begin{array}{l}\text { Área de } \\
\text { estudo }\end{array}$ & \multicolumn{2}{|c|}{26} & \multicolumn{2}{|c|}{161} & & \multicolumn{2}{|c|}{27} & \multicolumn{2}{|c|}{64} & \multicolumn{2}{|c|}{49} & \multicolumn{2}{|c|}{23} & 354 \\
\hline
\end{tabular}


QuAdro II - Focos mensais - período de seca.

TABLE II - Monthly fires - dry season.

\begin{tabular}{|c|c|c|c|c|c|c|c|c|c|c|c|c|c|c|c|c|}
\hline \multirow{2}{*}{ Mês } & \multicolumn{2}{|c|}{2010} & \multicolumn{2}{|c|}{2011} & \multicolumn{2}{c|}{2012} & \multicolumn{2}{c|}{2013} & \multicolumn{2}{c|}{2014} & \multicolumn{2}{c|}{2015} & \multicolumn{2}{c|}{2016} & \multirow{2}{*}{ Total } \\
\cline { 2 - 18 }$n$ & EEJBB & AID & EEJBB & AID & EEJBB & AID & EEJBB & AID & EEJBB & AID & EEJBB & AID & EEJBB & AID & \\
\hline Abril & 0 & 0 & 0 & 0 & 0 & 0 & 0 & 0 & 0 & 0 & 0 & 0 & 0 & 0 & 0 \\
\hline Maio & 5 & 2 & 0 & 0 & 0 & 0 & 0 & 0 & 0 & 0 & 0 & 0 & 0 & 0 & 7 \\
\hline Junho & 0 & 0 & 0 & 0 & 0 & 0 & 0 & 0 & 0 & 0 & 0 & 0 & 0 & 0 & 0 \\
\hline Julho & 0 & 5 & 5 & 5 & 0 & 3 & 0 & 1 & 0 & 0 & 0 & 1 & 2 & 17 & 39 \\
\hline Agosto & 0 & 4 & 0 & 7 & 0 & 1 & 0 & 3 & 5 & 12 & 0 & 17 & 0 & 0 & 49 \\
\hline Setembro & 0 & 7 & 40 & 103 & 0 & 0 & 5 & 18 & 8 & 31 & 0 & 23 & 0 & 0 & 236 \\
\hline Total & 5 & 18 & 45 & 115 & 0 & 4 & 5 & 22 & 13 & 43 & 0 & 41 & 2 & 17 & 331 \\
\hline
\end{tabular}

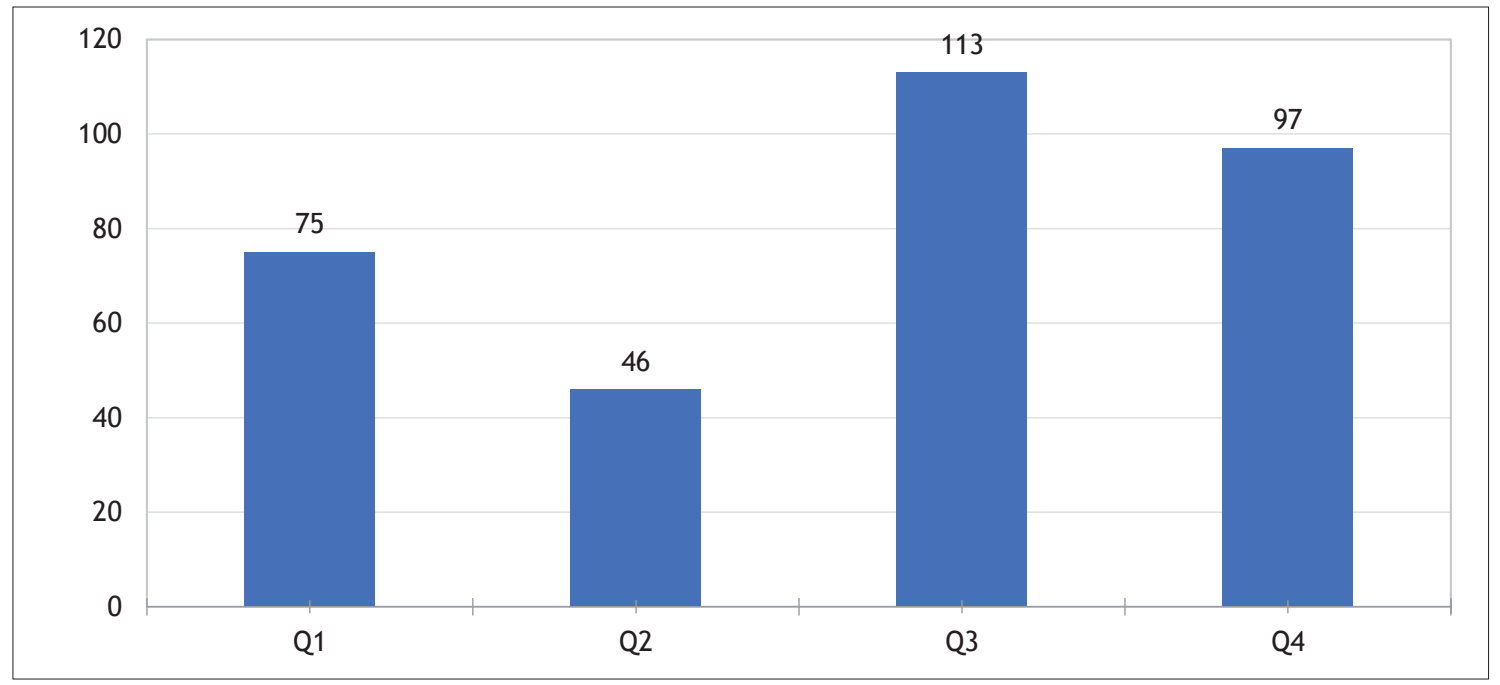

Fig. 5 - Focos por quadrante 2010 - 2016 / Seca.

Fig. 5 - Fires per quadrant 2010 - 2016 / dry season.

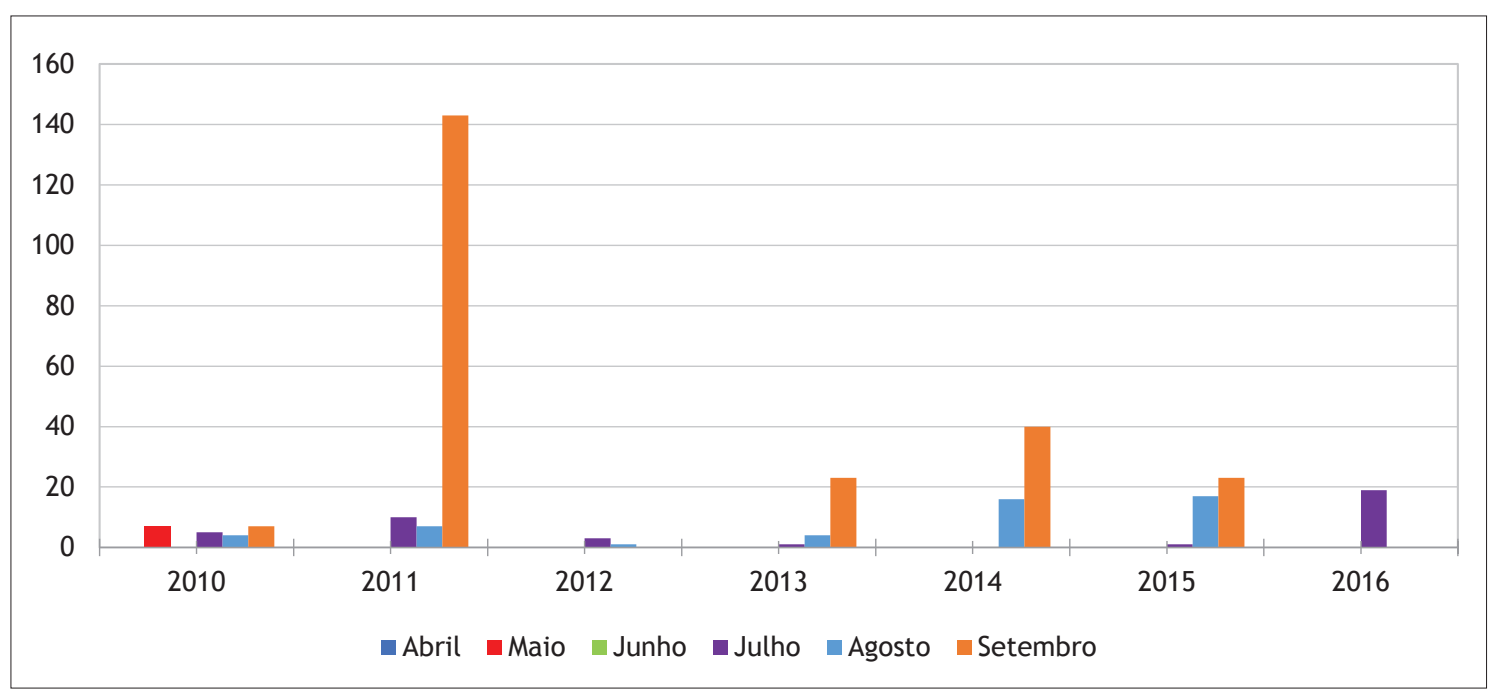

Fig. 6 - Focos mensais 2010- 2016 / Seca.

Fig. 6 - Monthly fires 2010 - 2016 / dry season. 
Para dar continuidade à análise desse quadro de criticidade observado no tempo de seca, durante os anos de 2010 a 2016, optamos por verificar de forma mais detalhada os registros de focos de calor do ano de 2011, no mês de setembro e nos dias 7, 8, 9 e 10, tendo em conta ser esta fase a mais crítica do período em estudo. A agregação por quadrantes $(Q)$ leva à verificação de que o Q1 e o Q4 constituem as áreas de maior incidência de registros, conforme QUADRo III e fig. 7 . Observando-se o contexto espacial (fig. 1, fig. 2) fica evidenciado que a prevalência de números de focos, portanto de maior risco, deriva, no ano de 2011, da relação de contato com zonas de baixa e média densidade de ocupação, ficando o Q3, na área delimitada pela rodovia DF001, em terceiro lugar no número de registros identificados.

Resta ainda observar a relação da localização dos registros, desses dias de setembro de 2011, com a variação de sua temporalidade. Os horários dos 140 pontos identificados na base do INPE, para efeito de análise, foram agregados em intervalos de 2 em 2 horas, no ciclo de 24 horas e considerando os 4 quadrantes, conforme QUADRo III. A partir dai foi possível concluir que 117 focos de calor estão incluídos no período de 12:01 às $24: 00$ h e perfazem $83,57 \%$ do total de focos.

Complementando a análise para outros períodos do dia, temos 83 focos identificados entre 12:01 e 18:00 h, que correspondem a $59,8 \%$. No período de $12: 01$ às $14: 00 \mathrm{~h}$ foram identificados 26 , correspondendo a $18,57 \%$. E, no período da madrugada, de 00:01 a 2:00 horas foram registrados 23 pontos, que constituem $16,2 \%$ do total de 140. Entre 2:01 e 12:00 h não há ocorrência de registros de focos na base de queimadas do INPE. Do mesmo modo, não ocorreram registros entre 14:01 e 16:00 h. Note-se que há prevalência de cobertura dos satélites no período vespertino e noturno.

Esta temporalização dos dados, acompanhada da análise espacial, conforme a localização nos quadrantes, permite apreender também a concentração dos focos ou sua propagação, tal como indicado nos quadrantes 1,3,4

QUADRO III - Focos por quadrante.

$T_{A B L E}$ III - Fires per quadrant.

\begin{tabular}{|c|c|c|c|c|c|}
\hline Dia & Quadrante 1 & Quadrante 2 & Quadrante 3 & Quadrante 4 & Total \\
\hline 07/set & 1 & 10 & 0 & 0 & 11 \\
\hline $08 /$ set & 20 & 5 & 5 & 26 & 56 \\
\hline 09/set & 10 & 0 & 16 & 42 & 68 \\
\hline $10 /$ set & 0 & 0 & 1 & 4 & 5 \\
\hline & 31 & 15 & 22 & 72 & 140 \\
\hline
\end{tabular}

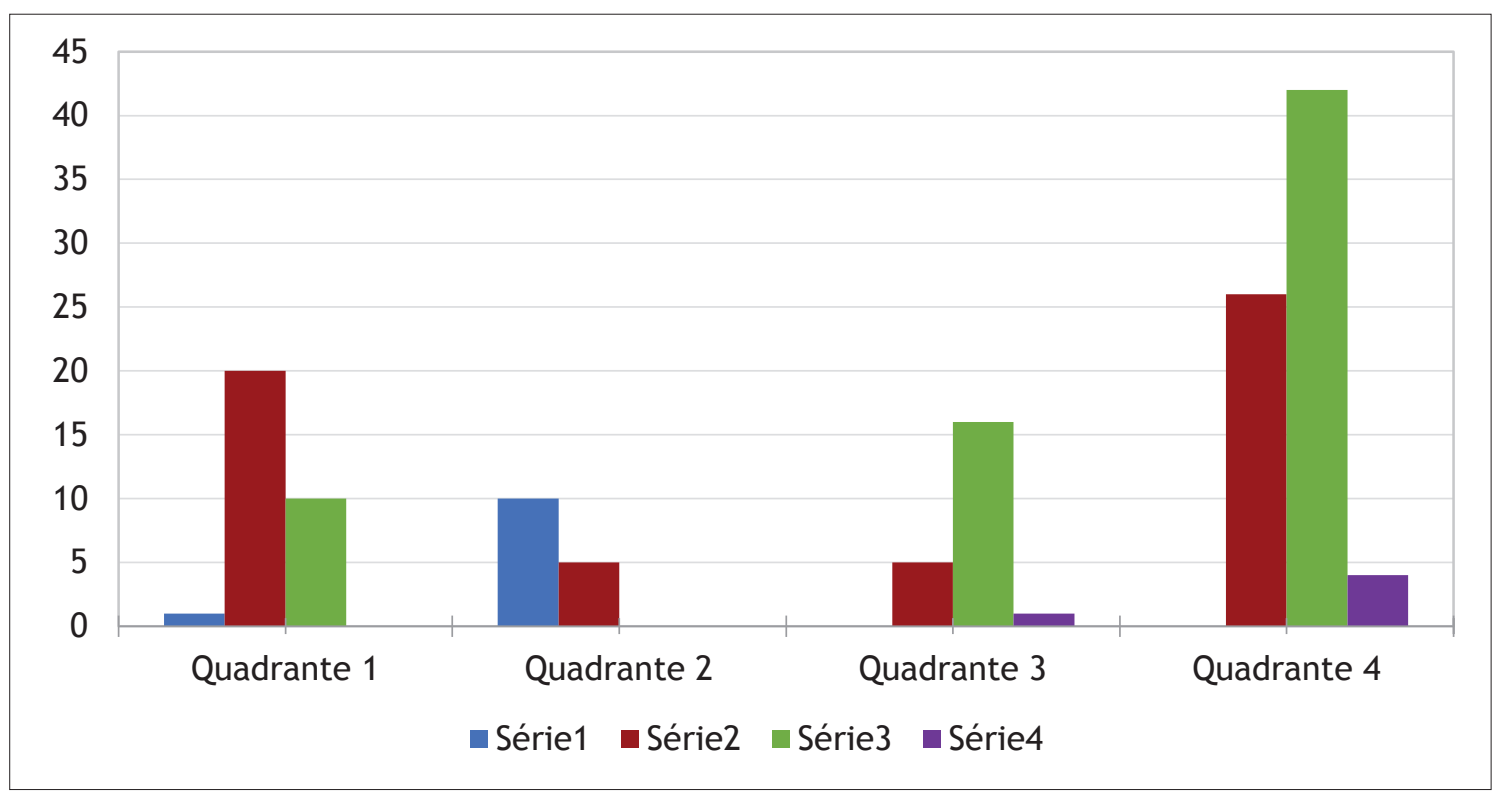

Fig. 7 - Focos por quadrante no período crítico de setembro de 2011.

Fig. 7 - Fires per quadrant in the critical period of September 2011. 
da fig. 8. Note-se que não há referência, neste caso, à intensidade desses focos, apenas a relação entre espaço e tempo está presente na elaboração. A separação por quadrantes, como exemplificado no QUADRo IV, ilustra não só os dias de maior número de registros, mas também os seus horários de maior incidência diária. Observe-se que é esperado um maior número de registros de focos de calor nos períodos do dia em que se conjugam, criticamente, diversos fatores, ou seja, altas temperaturas, baixíssima umidade relativa do ar e ventos com maior velocidade. O diferencial que se pode depreender nesta análise está relacionado ao peso a ser atribuído à dimensão territorial e sua conjugação aos fatores meteorológicos, já que o ato propulsionador da ignição é totalmente imponderável, mas possível de monitoramento e prevenção.

A relação de distribuição e de concentração será melhor aferida na sequência da pesquisa, que envolverá análise de registros de campo de agentes de combate e prevenção aos IF. Nos dados específicos do Quadrante 4, conforme fig. 9, é apreensível a sequência temporal de 10 horas consecutivas de focos, do período das $16: 01 \mathrm{~h}$ do dia 08 até 2:00 h do dia 09, com retorno de registros no período após as 12:00 h. A mesma análise é possível realizar para os demais quadrantes, em especial para aferir a dinâmica de início e ausência posterior de registros.
Dados meteorológicos do INMET relativos à situação crítica de 2011

A situação meteorológica dos dias 7, 8, 9 e 10 de setembro de 2011 foi reconhecida a partir de dados adaptados da base BDMEP, Estação 83377 (a mais próxima da área de estudo), do INMET. O QUADRo V, no período das 15:00 horas, indica a direção do vento de origem Norte (36 ou N), intercalada com a do Noroeste (32 ou NW), com umidade relativa do ar de 10 a $14 \%$, além de temperaturas de $30.5{ }^{\circ} \mathrm{C}, 31.1{ }^{\circ} \mathrm{C}$ e $32.3{ }^{\circ} \mathrm{C}$, respectivamente entre as menores taxas de umidade relativa do ar e as maiores temperaturas dos primeiros dez dias de setembro. Sendo que, nesse horário, no dia 09 e no dia 10 ocorrem as velocidades de 5 e $6 \mathrm{~m} / \mathrm{s}$, entre as mais elevadas em relação às demais medições de 1 a 10 de setembro, com exceção do dia 4, com 7 $\mathrm{m} / \mathrm{s}$. No período noturno, a medição realizada às $21: 00$ $\mathrm{h}$ indica situação de movimento de ar calma e umidade relativa acima de $30 \%$. Em paralelo, a fig. 8 apresenta uma sequência espacial de focos no dia 08 que pode ser relacionada à direção do vento Norte e ao fator do relevo em aclive, na direção da DF001, que está situada em linha de cumeada, na cota $1.130 \mathrm{~m}$.

Note-se que a prevalência da semana anterior entre os dias 1 e 06 de setembro no horário das 15:00 horas foi do vento

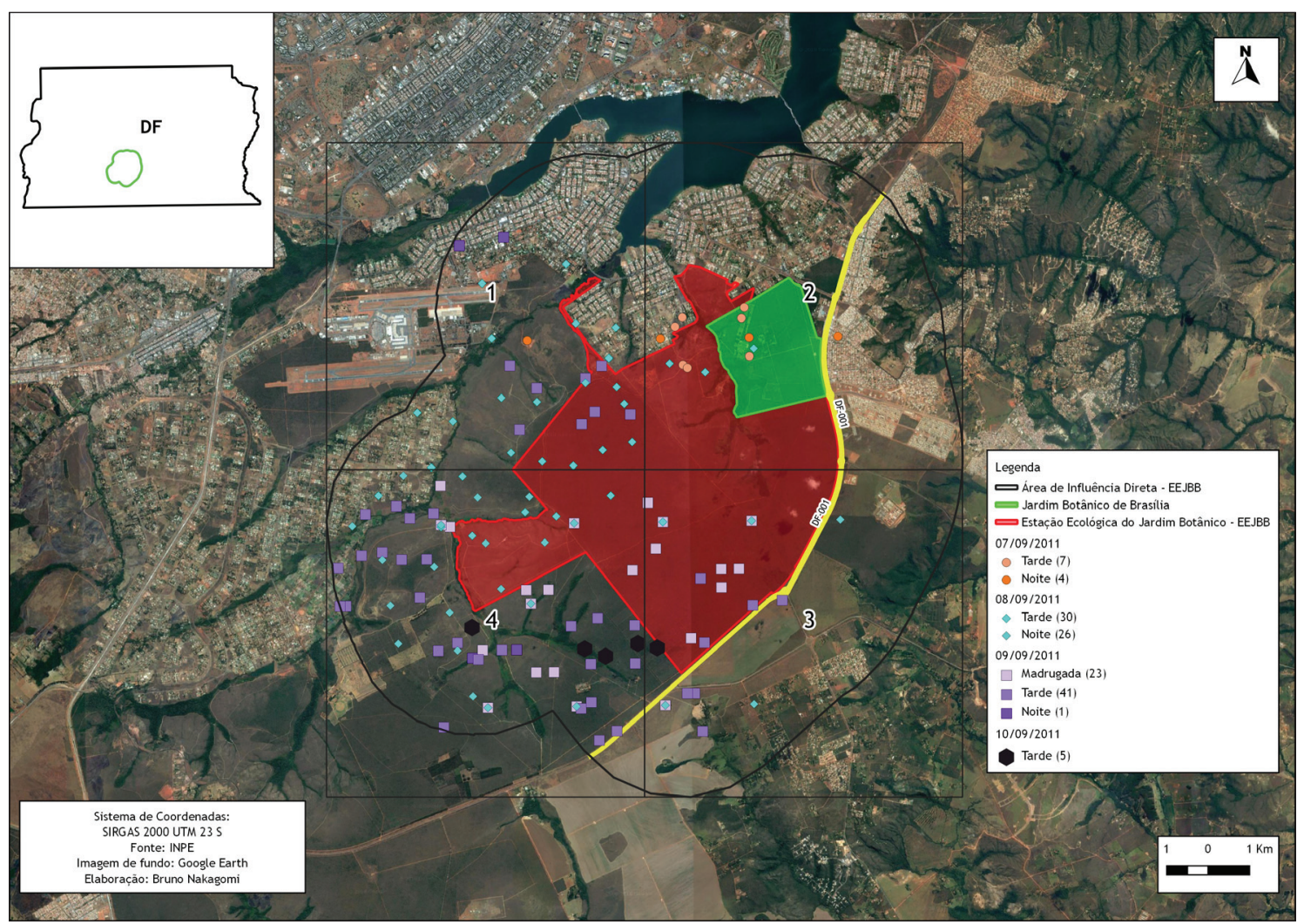

Fig. 8 - Focos de calor, por período do dia, em 7, 8, 9 e 10 de setembro de 2011.

Fig. 8 - Heat sources, by time of day, September 7, 8, 9 and 10, 2011. 
RISCOS - Associação Portuguesa de Riscos, Prevenção e Segurança

QuAdro IV - Quadro horário de focos nos dias 7, 8, 9 e 10 de setembro de 2011.

TABLE IV - Timetable of fires on 7, 8, 9 and 10 of September 2011.

\begin{tabular}{|c|c|c|c|c|c|c|c|c|c|c|c|c|c|c|c|c|c|}
\hline \multirow{2}{*}{$\begin{array}{c}\text { Quadro-Horário } \\
\text { Mês }\end{array}$} & \multicolumn{4}{|c|}{ Q1 } & \multicolumn{4}{|c|}{ Q2 } & \multicolumn{4}{|c|}{ Q3 } & \multicolumn{4}{|c|}{ Q4 } & \\
\hline & \multicolumn{16}{|c|}{ Setembro 2011 / N de focos } & \\
\hline Período horas/dia & 7 & 8 & 9 & 10 & 7 & 8 & 9 & 10 & 7 & 8 & 9 & 10 & 7 & 8 & 9 & 10 & Total \\
\hline 00:01:00-02:00:00 & & & & & & & & & & & 9 & & & & 14 & & 23 \\
\hline 02:01:00-04:00:00 & & & & & & & & & & & & & & & & & \\
\hline 04:01:00-06:00:00 & & & & & & & & & & & & & & & & & \\
\hline 06:01:00-08:00:00 & & & & & & & & & & & & & & & & & \\
\hline 08:01:00-10:00:00 & & & & & & & & & & & & & & & & & \\
\hline $10: 01: 00-12: 00: 00$ & & & & & & & & & & & & & & & & & \\
\hline 12:01:00-14:00:00 & & & 4 & & & & & & & & 3 & & & & 19 & & 26 \\
\hline $14: 01: 00-16: 00: 00$ & & & & & & & & & & & & & & & & & \\
\hline $16: 01: 00-18: 00: 00$ & & 19 & 4 & & 7 & 3 & & & & 1 & 4 & 1 & & 7 & 7 & 4 & 57 \\
\hline $18: 01: 00-20: 00: 00$ & & 1 & & & & 2 & & & & 4 & & & & 4 & & & 11 \\
\hline 20:01:00-22:00:00 & 1 & & 2 & & 3 & & & & & & & & & 9 & 2 & & 17 \\
\hline $22: 01: 00-24: 00: 00$ & & & & & & & & & & & & & & 6 & & & 6 \\
\hline Total & & & & & & & & & & & & & & & & & 140 \\
\hline
\end{tabular}

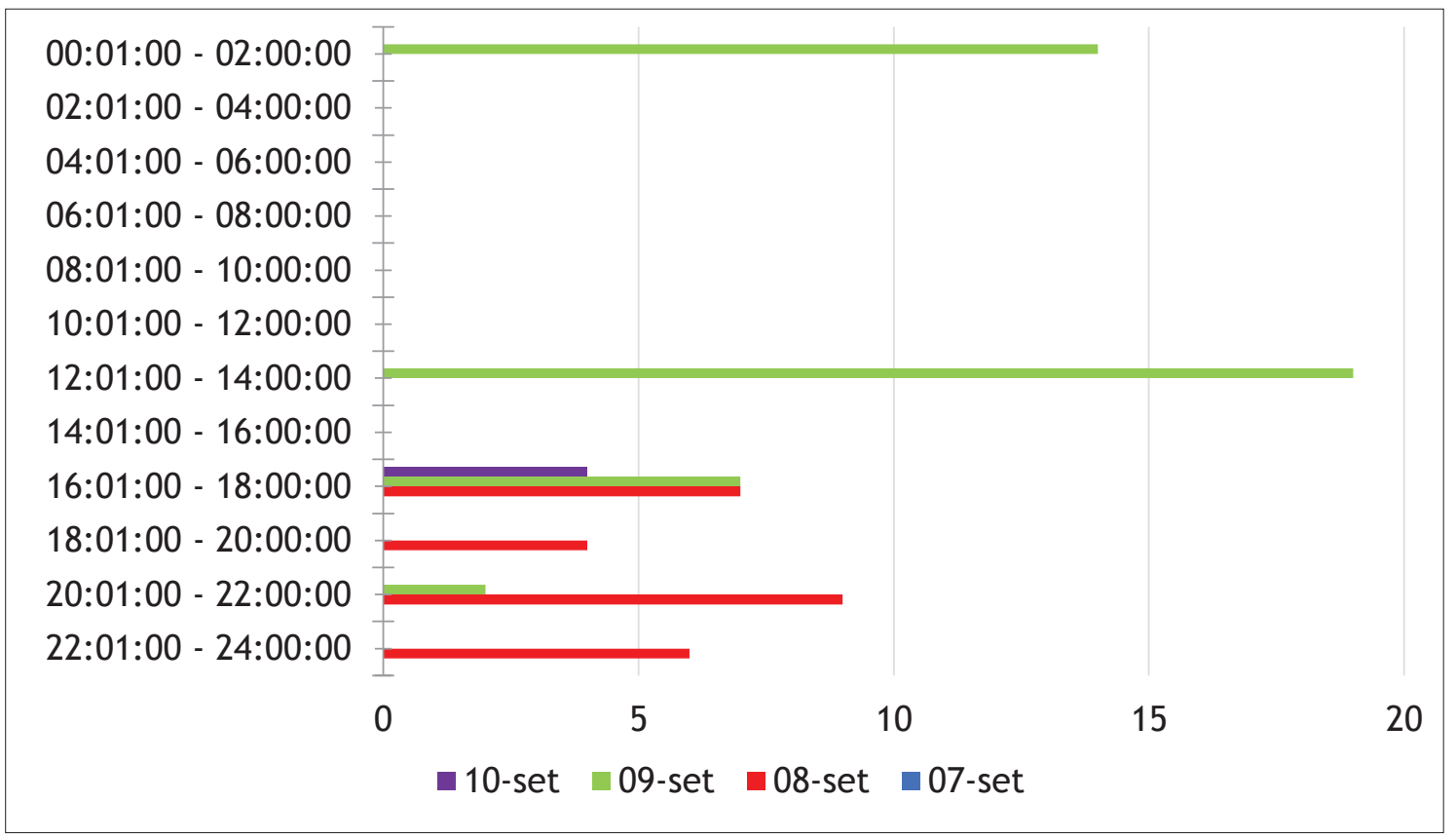

Fig. 9 - Focos por horários no quadrante 4.

Fig. 9 - Fires per time periods in quadrant 4.

Sudeste. Portanto, houve outra dinâmica de movimentos de ar na semana das ocorrências críticas. Por outro lado, é importante situar que o padrão no DF, no período de abril a setembro, segundo as Normais climatológicas do Brasil de 1961 a 1990, atualizadas no site do INMET, é o vento Leste, ou seja, como predominante, enquanto o restante do ano é classificado como calmo (INMET, sd). Conclui-se que as alterações circunstanciais na direção dos ventos, no período de seca, são um dos fatores de peso a considerar na análise dos dados de previsão de risco, tendo em vista a instrução dos requisitos do sistema de alerta, em proposição neste projeto de pesquisa. 
QuAdro V - Dados meteorológicos dos dias 07, 08, 09 e 10 de setembro de 2011 (INMET).

TABLE $V$ - Meteorological data for 7, 8, 9 and 10 September 2011.

\begin{tabular}{|c|c|c|c|c|c|c|c|c|c|c|c|c|c|c|c|c|}
\hline $\begin{array}{c}\text { Dados } \\
\text { meteorológicos }\end{array}$ & \multicolumn{3}{|c|}{$07 / 09 / 2011$} & \multicolumn{3}{c|}{$08 / 09 / 2011$} & \multicolumn{5}{c|}{$09 / 09 / 2011$} & \multicolumn{3}{c|}{$10 / 09 / 2011$} \\
\hline $\begin{array}{c}\text { Hora Oficial de } \\
\text { Brasília }\end{array}$ & $\mathrm{dv}$ & $\mathrm{vv}$ & $\mathrm{ur}$ & $\begin{array}{c}\mathrm{T} \\
{ }^{\circ} \mathrm{C}\end{array}$ & $\mathrm{dv}$ & $\mathrm{vv}$ & $\mathrm{ur}$ & $\begin{array}{c}\mathrm{T} \\
{ }^{\circ} \mathrm{C}\end{array}$ & $\mathrm{dv}$ & $\mathrm{vv}$ & $\mathrm{ur}$ & $\begin{array}{c}\mathrm{T} \\
{ }^{\circ} \mathrm{C}\end{array}$ & $\mathrm{dv}$ & $\mathrm{vv}$ & $\mathrm{ur}$ & $\begin{array}{c}\mathrm{T} \\
{ }^{\circ} \mathrm{C}\end{array}$ \\
\hline $09: 00$ & 36 & 4 & 16 & 25.4 & 5 & 3 & 22 & 25.5 & 0 & 0 & 21 & 26.8 & 0 & 0 & 31 & 24.5 \\
\hline $15: 00$ & 14 & 3 & 13 & 30 & 36 & 1 & 11 & 30.5 & 32 & 5 & 10 & 31.1 & 36 & 6 & 14 & 32.3 \\
\hline $21: 00$ & 5 & 1 & 22 & 23 & 0 & 0 & 31 & 23.2 & 0 & 0 & 31 & 23.2 & 0 & 0 & 35 & 23.2 \\
\hline
\end{tabular}

Fonte: Inmet, com dados adaptados à hora oficial de Brasília (direção do vento - $\mathrm{dv}$, velocidade do vento em $\mathrm{m} / \mathrm{s}$ - vv, umidade relativa do ar - ur, temperatura em ${ }^{\circ} \mathrm{C}$ ). Source: Inmet, with data adapted to the official time of Brasilia (wind direction - $d v$, wind speed in $\mathrm{m} / \mathrm{s}-\mathrm{v} \mathrm{v}$, relative air humidity - ur, temperature in $\left.{ }^{\circ} \mathrm{C}\right)$.

\section{Caracterização da paisagem e focos de calor}

A relação quantitativa e de distribuição de focos de calor na área de estudo foi realizada também segundo categorias de paisagem: antropizada urbana, antropizada agrícola ou vegetação natural, conforme fig. 10. Note-se o relativo equilíbrio numérico de focos nas distintas áreas antropizadas e a evidente maior concentração sobre a categoria de cobertura vegetal nativa. 0 detalhamento sobre o tipo de vegetação afetada na EEJBB, conforme préclassificação paisagística do respectivo Plano de Manejo (DF, 2010), aponta para a necessidade da qualificação e mapeamento prévio do território quanto à cobertura vegetal, tendo em vista a gestão de situações críticas em que a relação da velocidade de propagação e persistência das ocorrências depende da massa de combustível vegetal e da sua potencial de resistência ao fogo (fig. 11).

O mapeamento, conforme fig. 11, de focos de calor de 2010 a 2016 sobre o tipo de vegetação da EEJBB revela que foram afetadas, em valores numéricos, as seguintes áreas: campo de murunduns (3), campo limpo (6), Cerrado ralo (1), Cerrado típico (48) e mata de galeria (3). Desta abordagem, se destaca a relação com o Cerrado típico (com presença arbórea e arbustiva), que domina a paisagem da EEJBB e está situada privilegiadamente nos quadrantes 1 e 3 . A presença de maioria de focos sobre o cerrado típico, com presença de vegetação arbórea, e em Mata de Galeria, que corresponde a área úmida e florestada, é indicativa da intensidade e gravidade do quadro de riscos, nesse período estudado.

Por outro lado, o acesso à caracterização detalhada das fisionomias do Cerrado para o restante da área de envolvência da EEJBB vai exigir trabalho de campo exaustivo, identificação e compilação de outras fontes, considerando que estudos de classificação de imagens de satélite disponíveis tendem a homogeneizar a variedade paisagística do Cerrado. No entanto, a comparação deste período com a situação resultante do incêndio florestal de 2005 conduz ao caráter de recorrência e identificação aproximada das mesmas zonas de origem dos focos (S. Correa, 2007).
Este quadro demonstra a necessidade de monitoramento dos fatores do ordenamento territorial facilitadores do processo de recorrência e de ações que contribuam para observar as transformações paisagísticas do Cerrado decorrentes da frequência dos incêndios florestais.

\section{A produção voluntária de informação geográfica}

Essas interações dependem de análises e monitoramento continuados da parte do poder público, porém já observamos a dificuldade existente quanto à infraestrutura de dados locais mais precisos. No entanto, cabe destacar que os atos causadores de queimadas e os decorrentes incêndios florestais ao atingirem unidades de conservação, situadas em território de urbanização progressiva, demandam dos agentes públicos a necessidade de atuar preventivamente no contato com as populações locais, responsáveis em geral pela origem dos focos de incêndio, mas também pela informação mais breve da ocorrência.

Nessa linha de investigação, tendo em vista a situação de recorrência dos incêndios florestais e a extensão de áreas atingidas, é que se propõe a utilização da colaboração voluntária na produção de informações geográficas que contribuam para a detecção precoce das ocorrências. A metodologia aqui apresentada de sistematização e análise dos dados retirados da base de queimadas do INPE e do INMET permitiu esta caracterização da área de estudo afetada pelos incêndios florestais. Os mesmos procedimentos poderão ser adotados para circunscrever outros cenários do DF, conjugados posteriormente a análises de suscetibilidade de longo prazo. Visa-se, assim, a identificação de territórios de risco e aperfeiçoamento de requisitos para estruturação de camadas de mapeamento do sistema de alerta, objeto de proposição deste projeto de pesquisa multidisciplinar.

A produção voluntária de informações geográficas, conjugada à gestão de riscos, tem sua relevância colocada na escala de observação e no reconhecimento local do problema, considerando que os habitantes da 


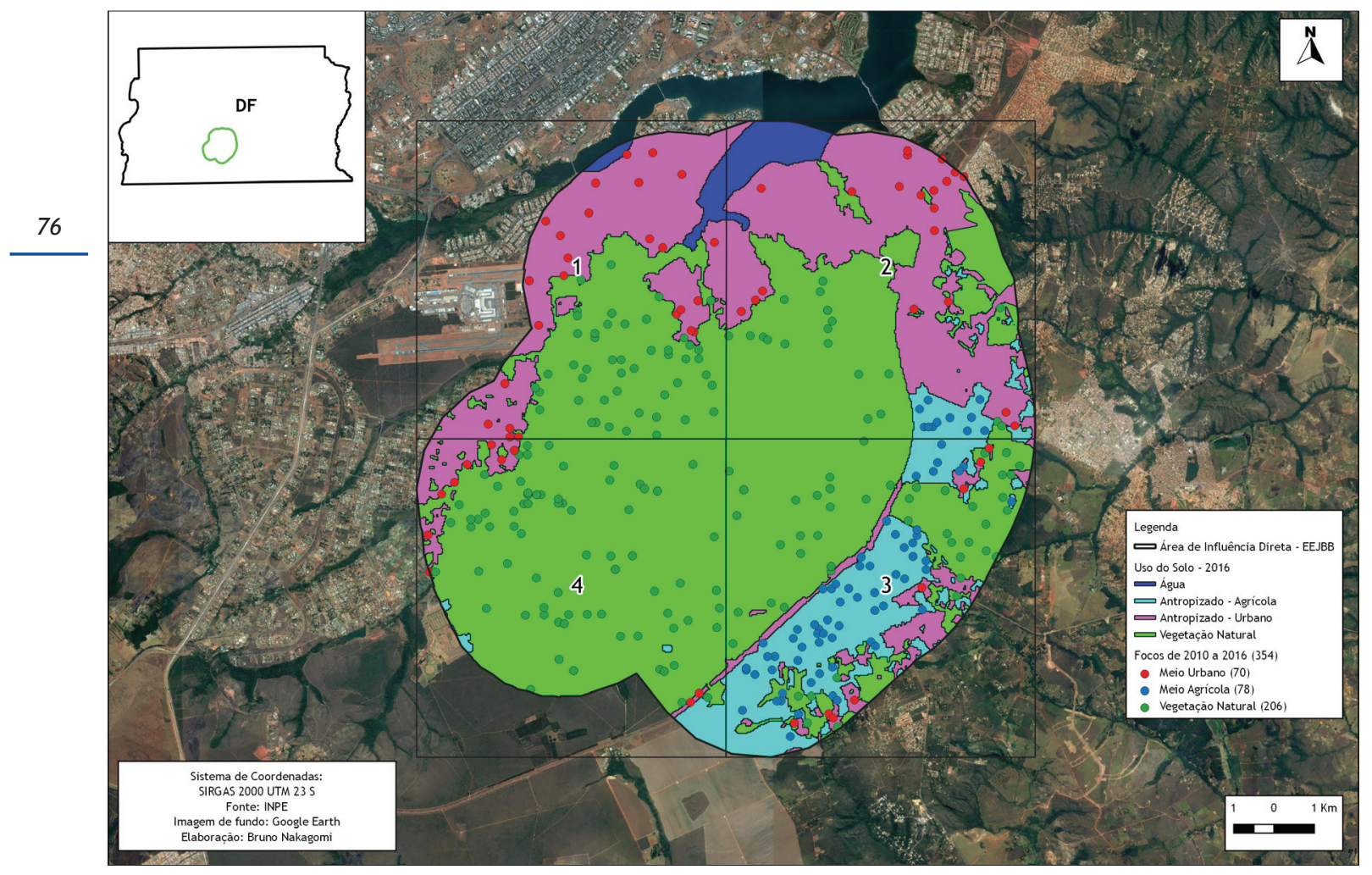

Fig. 10 - Focos de calor e categorias de paisagem.

Fig. 10 - Heat sources and landscape categories.

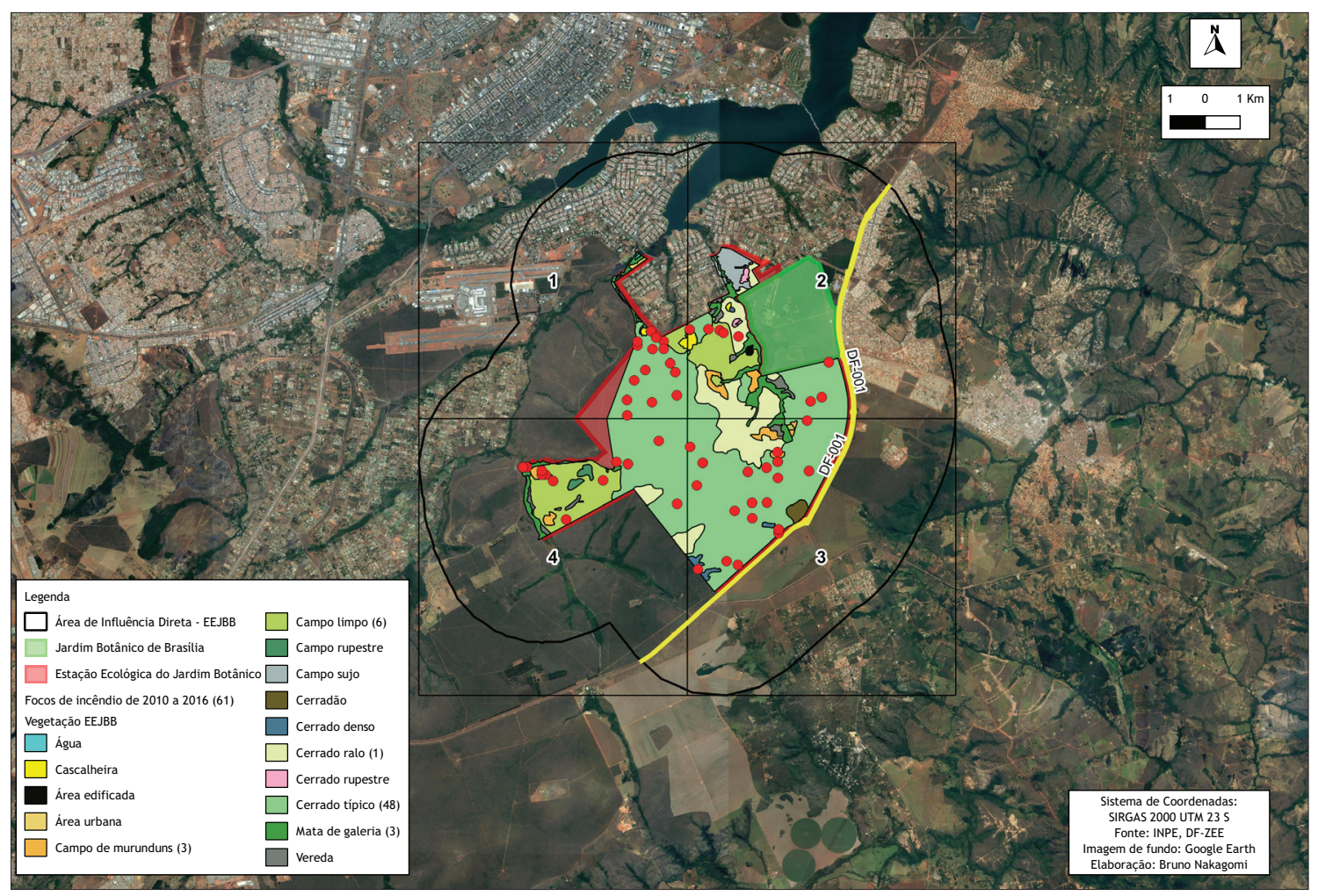

Fig. 11 - Focos de calor de 2010 a 2016 sobre o tipo de vegetação da EEJBB.

Fig. 11 - Heat sources from 2010 to 2016 over EEJBB's vegetation. 
envolvência de áreas atingidas por incêndios florestais serão, se incorporados aos processos de gestão de riscos, os melhores agentes a favor da prevenção.

A estratégia do projeto do sistema de alerta consiste em incrementar a participação social no processo de detecção e favorecer a gestão da informação e tomadas de decisão em situação crítica, com notificações em tempo real. Inclui, ainda, orientar, em atividades de observação direta, a realização de registros fotográficos para monitoramento dos efeitos de queimadas nas paisagens do Cerrado, considerando o crescimento do número de ocorrências de incêndios, as perspectivas de mudanças climáticas e a tendência à urbanização sobre áreas protegidas em Brasília, DF.

A produção de informação geográfica nessa temática também contribuirá para estudos de percepção ambiental, com localização de dados e sistematização de séries históricas.

Considera-se que a produção da informação geográfica e imagética por voluntários no período crítico ou na observação pós - queimada remete a momentos diversos de apreensão do mesmo problema. Contudo, na primeira situação pressupõe-se uma consciência do risco imediato e o ato de registro da notificação é livre. Já na outra vertente o objetivo é disseminar a observação dos efeitos negativos e ampliar a consciência dos riscos de longo prazo inerentes à propagação de fogo nas áreas de cerrado situadas em meio urbano.

Entendem-se essas duas fases da produção voluntária de informação geográfica como formas colaborativas, de um lado, na execução de políticas públicas de prevenção e gestão de riscos, nos termos de crowdsourcing, e, de outro, na investigação sobre efeitos de médio e longo prazo dos incêndios florestais na transformação das fisionomias do Cerrado em situação de envolvência urbana, como práticas de citizen science.

\section{A Análise de Requisitos para o Sistema de Alerta}

A utilização do aplicativo, em sistema Android, pela população, com envio de notificações de texto, áudio ou imagem fotográfica, constitui o fato gerador da informação no sistema, em processo de desenvolvimento, que dependerá, no entanto, de fontes diversificadas para aferir completude e qualidade dos dados. 0 reconhecimento das zonas envolventes de áreas protegidas e suas tipologias de ocupação e uso do solo, consideradas na recorrência de relação histórica com os incêndios florestais, constituirá uma das camadas de informação para identificação de territórios de risco. No entanto, outras camadas de mapeamento serão também incorporadas para compor a análise de dados, desde a indicação de logística de apoio à atuação de corpo de bombeiros, infraestrutura de serviços de hidrantes, caracterização de dificuldades de acessos e de trânsito em vias locais, além de níveis de declividade. Os dados meteorológicos e os dados de focos de calor do INPE, em séries históricas e em tempo real, serão também incorporados ao sistema.

Note-se que as unidades de conservação do DF, de vinculação estadual, são as entidades responsáveis, no primeiro estágio da informação, por gerir ocorrências de risco de incêndio em seu território com apoio de uma brigada de voluntários (DF, 2016 b). 0 projeto do sistema de alerta, representado na fig. 12, visa criar as condições de infraestrutura computacional para agilizar o processo de gestão da informação do Plano de Combate e Prevenção a Incêndios Florestais do DF, considerando todos os estágios de planejamento e combate às situações críticas. Contudo, prioritariamente pretende-se acelerar os procedimentos de monitoramento e controle no estágio inicial das ocorrências. A metodologia aplicada de fusão de dados, que envolve diversidade de fontes de informação, analisará procedimentos dos agentes e processos decisórios.

Antes de explorar o processo de fusão, foi necessário estruturar uma fase de análise de requisitos, iniciando com uma entrevista não estruturada, aplicada para a exploração do caso, para conhecer melhor o domínio e as variáveis que o compõe. 0 objetivo foi a obtenção das informações, tarefas e objetivos envolvidos na análise de situações, gerando um documento chamado de Análise de Tarefas Dirigida por Objetivos (Goal-Driven Task Analysis - GDTA). Esta entrevista foi feita com os integrantes do Corpo de Bombeiros de Brasília - para definir o que é mais relevante para eles e qual é a diferença que cada informação faz na decisão que deve ser tomada.

De acordo com os resultados da entrevista e a criação do GDTA, é possível identificar as palavras mais relevantes para o domínio, trazendo os tópicos das principais informações que devem ser identificadas em um alerta. Dessa forma, a representação de entidades que são importantes para a tomada de decisão foi definida. Como objetivo geral das ações do Corpo de Bombeiros, "preservar o meio ambiente, a vida e o patrimônio".

Primeiramente, deve-se determinar a natureza preliminar da emergência para a alocação dos recursos, levando em consideração o tipo da emergência (incêndio, acidente, atendimento médico), o local e a existência de vítimas, como é visto com a representação do GDTA na fig. 13 .

Após encontrar estes dados, é necessário determinar a natureza concreta da emergência para a alocação definitiva da equipe. Para tal, caracterizar as denúncias é parte vital do trabalho. Informações importantes em casos de incêndios estão indicadas nas fig's 14 e 15, lembrando que essas informações foram recolhidas da entrevista não estruturada feita com os integrantes do Corpo de Bombeiros de Brasília (contida no Anexo A). 


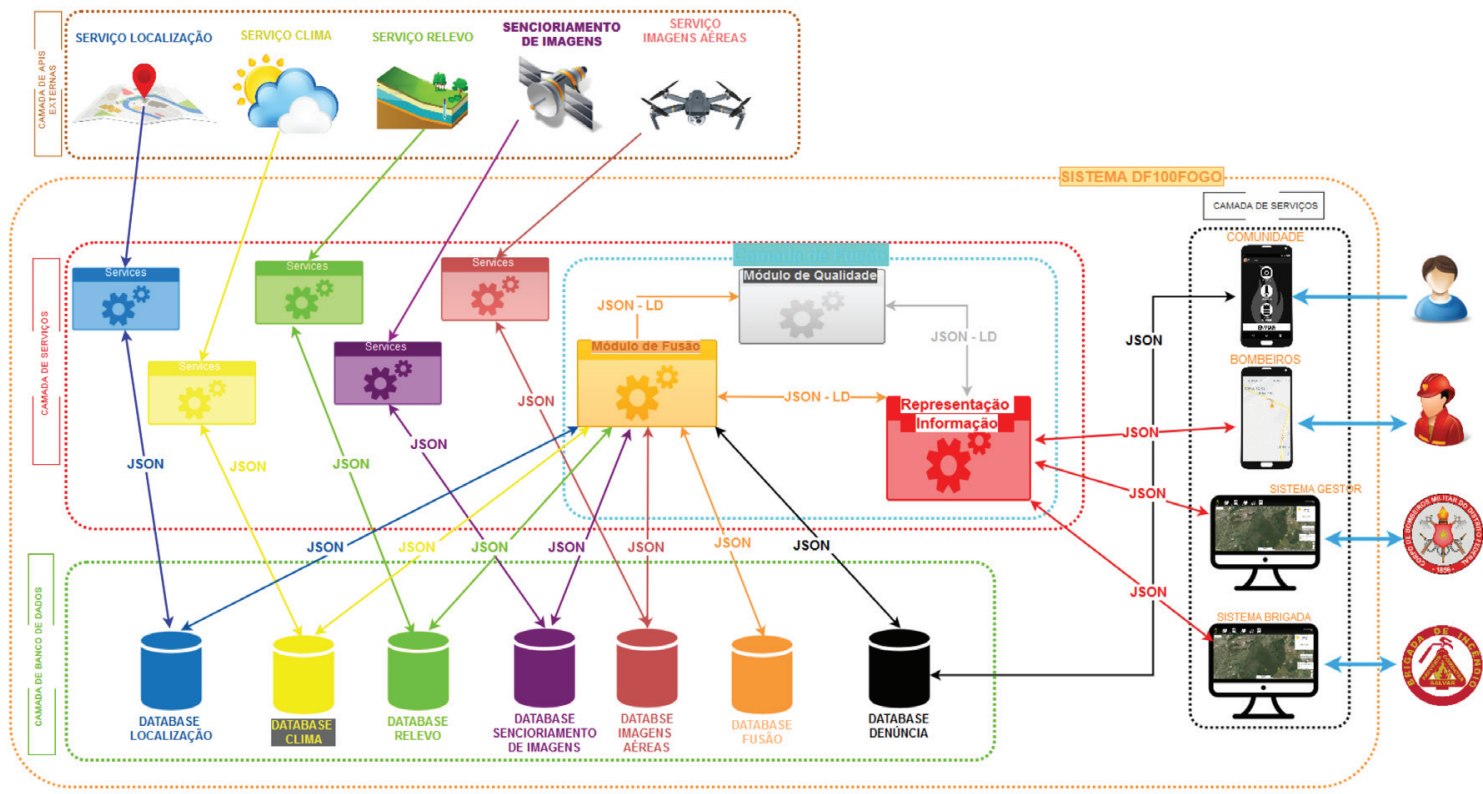

Fig. 12 - Arquitetura do sistema.

Fig. 12 - System architecture.

\begin{tabular}{|c|c|c|c|}
\hline \multicolumn{2}{|c|}{ local (rua, bairro, referencia) } & \multirow{2}{*}{$\begin{array}{l}\text { INf 3.1: } \\
\text { INF 3.2: }\end{array}$} & \multirow[b]{2}{*}{ DEC 3.1: caracterizar preliminarmente as denúncias SAW 2} \\
\hline tipo da emergência (incendio, aciden & tendimento medico) & & \\
\hline condição & existência de vítimas & INF 3.2 & \\
\hline
\end{tabular}

Fig. 13 - GDTA: determinar a natureza preliminar da emergência.

Fig. 13 - GDTA: determine the preliminary nature of the emergency.

DEC 2.1: caracterizar as denúncias 193 da emergência SAW 1

SUB 1.2: determinar a natureza concreta da emergência para a alocação definitiva d€ recursos

Fig. 14 - GDTA: determinar a natureza concreta da emergência.

Fig. 14 - GDTA: determine the actual nature of the emergency.

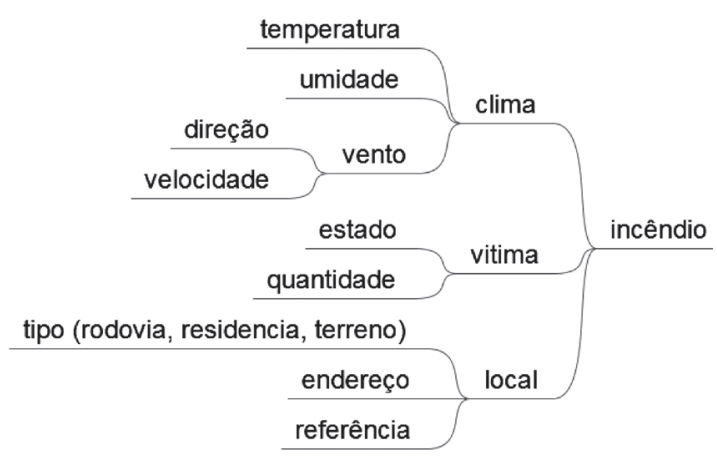

Fig. 15 - GDTA: Informações cruciais para a tomada de decisão.

Fig. 15 - GDTA: Critical information for decision making.
Dessa forma, há a identificação das informações cruciais que devem ser levadas em conta na fusão de dados e informações (que será explicada posteriormente), criando uma estrutura que servirá como modelo para a fusão

Processo de Fusão de Dados do DF100Fogo

A fusão de dados e informações de múltiplas fontes desenvolvida neste trabalho tem o modelo JDL como base, em que a fusão de dados auxilia diretamente na consciência situacional da equipe especialista do domínio. Este trabalho não terá como foco a qualidade de dados, e sim a fusão e como esta pode contribuir para análise de situações. 
Considerando os níveis 1, 2 e 3 do modelo JDL, foi proposto um processo dividido em três módulos, integrados aos níveis de fusão já mencionados nos capítulos anteriores. Para obter indícios de que a fusão de dados e informações pode ser aplicada em um contexto como o do projeto DF100Fogo, foi desenvolvido como base um processo para a obtenção de avisos de incêndio e a transformação do mesmo em uma situação. Seu fluxo pode ser visualizado na fig. 16.

O processo de fusão de dados e informações proposto é separado em três fases: a fase 1, da qual consiste em obter o alerta e fazer uma verificação gramatical de todo o seu texto, identificando verbos, seu tempo verbal, palavras em singular e plural, entre outros.

$\mathrm{Na}$ fase dois, é feita uma estruturação do alerta e quais informações devem ser buscadas em seu texto. 0 próximo passo é identificar as palavras relevantes, criando um novo conjunto de informações selecionadas de acordo com a estrutura que foi criada anteriormente, salvando-a em um banco de dados criado especialmente para o armazenamento de alertas já em fase de fusão, contendo somente informações prioritárias para a tomada de decisão.

Com os passos anteriores concluídos, é iniciada a fase 3 do processo, identificando a sinergia de informações dos alertas, fundindo as informações complementares. Para a criação de uma situação final com mais relevância, o último passo é a requisição de dados climáticos em uma API de um site de meteorologia, identificando a condição climática e relacionando-a com as informações encontradas no alerta. É feita uma comparação entre elas, trazendo um possivel resultado de projeção futura, do que poderá acontecer com aquele caso de incêndio, podendo se alastrar ou ser contido pela equipe com rapidez e facilidade.

\section{Resultados e discussão}

\section{O sistema de alerta - estrutura e processos decisórios}

A proposição do sistema de alerta (DF100Fogo), que advém de parcerias institucionais entre IBICT, UFSCar,
JBB, além da UNIVEM, traça dois focos de intervenção com dimensões inovadoras: a interação com sociedade local e o monitoramento em tempo real, com utilização de geolocalização, estruturação de camadas com mapeamento de territórios de risco, e fusão de dados de diversas fontes dinâmicas. Esta estrutura do sistema, que dá suporte ao processo integrador de dados e facilitador de tomada de decisões em situações críticas, direciona a pesquisa em tecnologias de informação e comunicação, cuja experimentação em serviço público local será realizada pelo Corpo de Bombeiros Militar do DF, entidade responsável diretamente pelo combate aos incêndios florestais, com apoio das brigadas locais.

O DF100Fogo inclui um aplicativo móvel para o sensoriamento participativo da comunidade (crowdsourcing), que tem a função de enviar notificações/avisos sobre focos de incêndio, sob forma de áudio, foto e texto (fig. 12).

Em complemento, há uma aplicação servidora que processa, integra e relaciona dados de diversas fontes complementares às notificações. Um sistema administrador permite ainda a visualização das informações de situações de incêndio em mapa georreferenciado (fig. 12).

Os avisos podem ser visualizados também em um aplicativo desenvolvido especialmente para os brigadistas e bombeiros da região do DF, que fazem a patrulha no local, facilitando o deslocamento de equipes de combate e alocação de recursos (fig.12).

\section{Fase 1 - Obtenção e Preparação dos Dados}

O primeiro passo desse fluxo foi a obtenção de um alerta de incêndio. Foram identificadas duas formas para conseguir esses dados:

a) A criação de um falso alerta, um texto simples descrevendo uma ocorrência de incêndio;

b) Uso de alertas já existentes no sistema de gestão do DF100Fogo, que recebe informações da comunidade para o auxílio do combate ao incêndio.
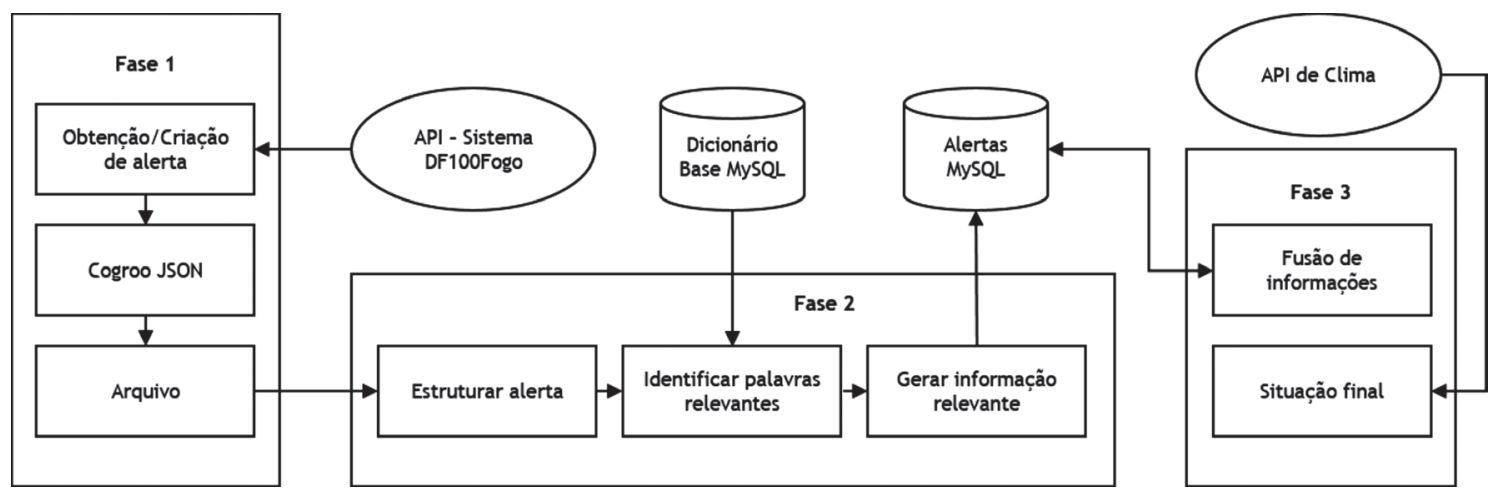

Fig. 16 - Processo de fusão de dados e informações.

Fig. 16 - Process of merging data and information. 
Esta fase corresponde ao nível 0 de fusão de dados, seguindo o modelo JDL. Lembrando que, para este trabalho, é utilizado somente o texto da notificação, de forma totalmente manual. É interessante também citar que existem funcionalidades para transcrever o áudio enviado, contribuindo para obter mais dados da notificação.

Identificando frases que podem ser consideradas como exemplo de texto enviado nos alertas via aplicativo:

- “O fogo está na direção da rua 00 no lago oeste, mas para dentro do parque nacional";

- $\quad$ "Está acontecendo um incêndio no parque nacional a chama está com um metro e meio mais ou menos e a fumaça está preta";

- "Uma pessoa se queimou no parque nacional tentando apagar as chamas e precisa de atendimento urgente"
Com estes exemplos, temos as informações iniciais necessárias para a tomada de decisão do Corpo de Bombeiros, pois identifica a existência de fogo, fumaça, vítima e referências sobre o local da ocorrência e pontos de localização. As palavras esperadas no processo de fusão são demonstradas na QUADRo VI.

Transformamos o texto do aviso em um JSON (JavaScript object Notation) criado por uma biblioteca criada na linguagem Java chamada Cogroo (http://cogroo. sourceforge.net/). Inicialmente, o Cogroo é utilizado como corretor gramatical acoplável ao LibreOffice, editor de textos open-source; porém, é possível utilizar a biblioteca para a obtenção do JSON que é utilizado no editor para a correção gramatical. Com a obtenção deste objeto, o mesmo foi salvo como um arquivo com a extensão “.json” para futuras consultas. Um exemplo deste JSON foi criado e está contido nas fig's 17 e 18.

QUADRO VI - Dados esperados para a fusão.

$T_{A B L E}$ VI - Expected data for merging.

\begin{tabular}{|c|c|c|}
\hline Categoria & Dados esperados & Exemplos \\
\hline \multirow{2}{*}{ Fogo } & Palavra de referência & $\begin{array}{l}\text { Fogo, fogaréu, chama (s), incêndio, } \\
\text { queimada }\end{array}$ \\
\hline & Tamanho (qualitativo ou quantitativo) & $\begin{array}{l}\text { Um metro, um metro e meio, dois } \\
\text { metros, alto, baixo, grande, pequeno }\end{array}$ \\
\hline \multirow{4}{*}{ Fumaça } & Palavra de referência & Fumaça \\
\hline & Cor & $\begin{array}{l}\text { Branco, preto, marrom, amarelo, } \\
\text { vermelho, verde }\end{array}$ \\
\hline & Espessura & Grossa, fina, forte, fraca \\
\hline & Status & $\begin{array}{l}\text { Embranquecer, aumentar, diminuir, } \\
\text { reduzir }\end{array}$ \\
\hline \multirow{4}{*}{ Local } & Conjunto de palavras para referência & $\begin{array}{l}\text { Próximo, perto, longe, distante, frente, } \\
\text { atrás, lado }\end{array}$ \\
\hline & Direção & Direção, sentido \\
\hline & Locais próximos & Lago, parque, centro, zona \\
\hline & Proximidade a moradias & $\begin{array}{l}\text { Rua, avenida, prédio, casa, residencial, } \\
\text { residência, condomínio }\end{array}$ \\
\hline \multirow{3}{*}{ Vitima } & Quantidade & Uma, duas \\
\hline & Palavra de referência & $\begin{array}{l}\text { Pessoa (s), moça, mulher, cara, homem, } \\
\text { menina, menino, moleque, indivíduo }\end{array}$ \\
\hline & Estado da vítima & $\begin{array}{l}\text { Sangrando, machucado, queimado, } \\
\text { ferido, grave }\end{array}$ \\
\hline Palavras relevantes & $\begin{array}{l}\text { Palavras que auxiliem no entendimento da } \\
\text { situação, mas que não cabem diretamente } \\
\text { em alguma dessas categorias }\end{array}$ & Muro, nascente, asfalto, praça \\
\hline
\end{tabular}




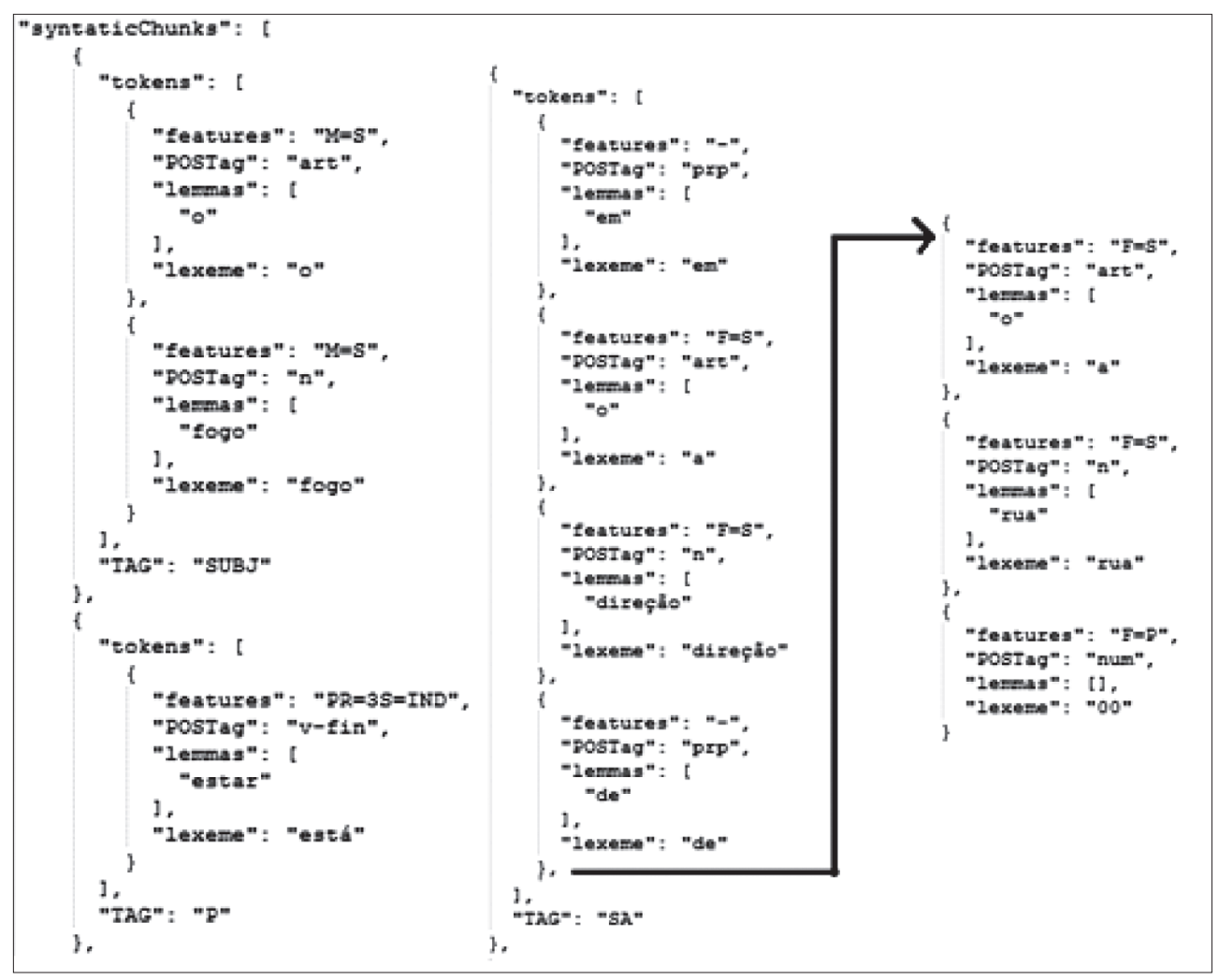

Fig. 17 - JSON produto da biblioteca Cogroo.

Fig. 17 - JSON CoGroo library product.

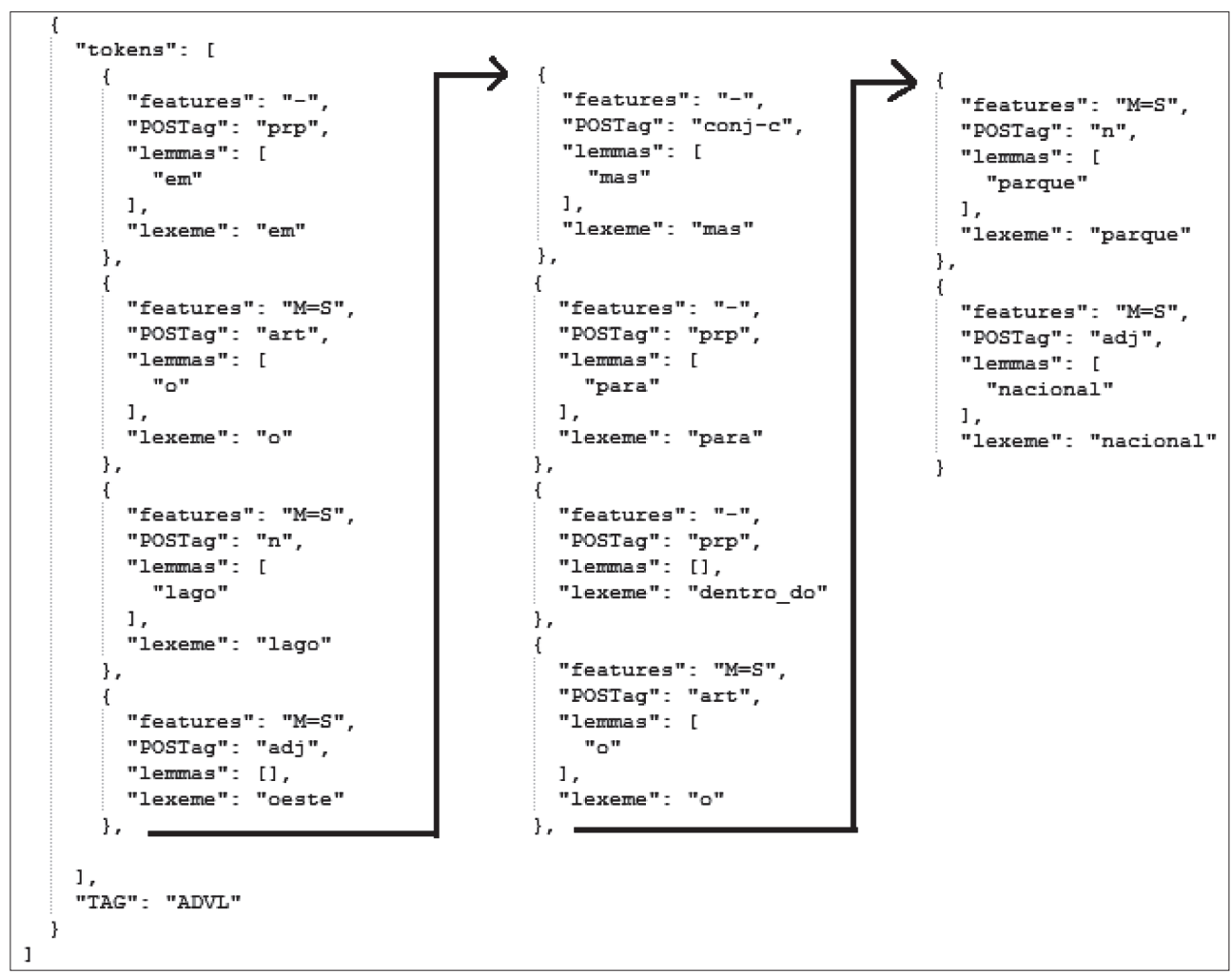

Fig. 18 - Continuação e finalização do JSON produto da biblioteca Cogroo.

Fig. 18 - Continuation and finalization of the JSON CoGroo library product. 
A importância da biblioteca Cogroo para o trabalho vem para a classificação e identificação de toda e qualquer classe gramatical das palavras contidas no texto, identificando pronomes, artigos, verbos, números e palavras em singular e plural. Dessa forma, não há a necessidade de redundância na procura de palavras. Pode-se citar como exemplo a palavra "está", que é produto do verbo "estar", destacadas na fig. 17. No conjunto "lemmas", é possível identificar o verbo "estar", radical da palavra contida no conjunto "lexeme", que identifica a palavra "está" mostrada como a forma original da escrita do alerta.

É importante citar que as palavras esperadas no processo de fusão, mostradas no QUADRO VI, foram deduzidas de acordo com informações recolhidas no GDTA e na entrevista feita com o Corpo de Bombeiros, criando palavras-chave para a identificação de um caso de incêndio. Com essas palavras, foi criado também um dicionário base que será utilizado na fusão de dados, criando referências para a busca de palavras-chave do domínio. Para tal, o dicionário foi armazenado em banco de dados relacional - MySQL, gerando termos gerais (fogo, fumaça, local, vítima e outros) e específicos (cada termo geral terá palavras semelhantes ao contexto).

\section{Fase 2 - Identificação da Situação}

Esta é a primeira fase da fusão de dados que cria uma estrutura que seja entendida pelo computador. O JSON salvo anteriormente é requisitado para essa fase, varrendo os conjuntos de dados nele contidos e comparando cada palavra com os termos específicos do dicionário base, com o fim de entender a qual tipo de informação aquela palavra que é verificada naquele momento está relacionada. Seu fluxo é ilustrado na fig. 19.
Detalhando um pouco mais com um exemplo: o JSON salvo é comparado conjunto a conjunto e palavra por palavra com o dicionário criado. Supondo que existe a palavra "incêndio" no JSON; esta deve ser comparada aos termos específicos relacionados a fogo e identificada. Dessa forma, ela será separada em um novo conjunto de dados, que terá dados mais precisos e que será armazenado para análises posteriores. Como incêndio está relacionado somente a fogo, as demais comparações feitas no algoritmo não terão novos resultados, porém já existe algo para a criação da situação. Esta operação será feita com todas as palavras encontradas no JSON e relacionadas a seus respectivos termos gerais, como mostrado na fig. 20.

Após essa fase, a fusão vai para a sua fase final, para a fusão de situações semelhantes e a projeção da mesma num futuro próximo, auxiliando na obtenção de consciência situacional e na tomada de decisão dos operadores.

\section{Fase 3 - A Fusão de Informações e Projeção do Futuro}

Depois de concluir a operação acima, será criado um conjunto de dados mais precisos sobre aquele comunicado. Dessa forma, há uma nova análise para a comparação com outros avisos que já foram analisados anteriormente. Caso não existam informações anteriores, o atual será gravado no banco de dados para futura consulta. Se já existirem dados sobre outros alertas, estes serão comparados com o atual, tentando encontrar uma relação da data do alerta e o local que o mesmo acontece, a fim de estabelecer uma conexão entre os mesmos. Se a comparação de local for positiva, o próximo passo da fusão acontece, somando as

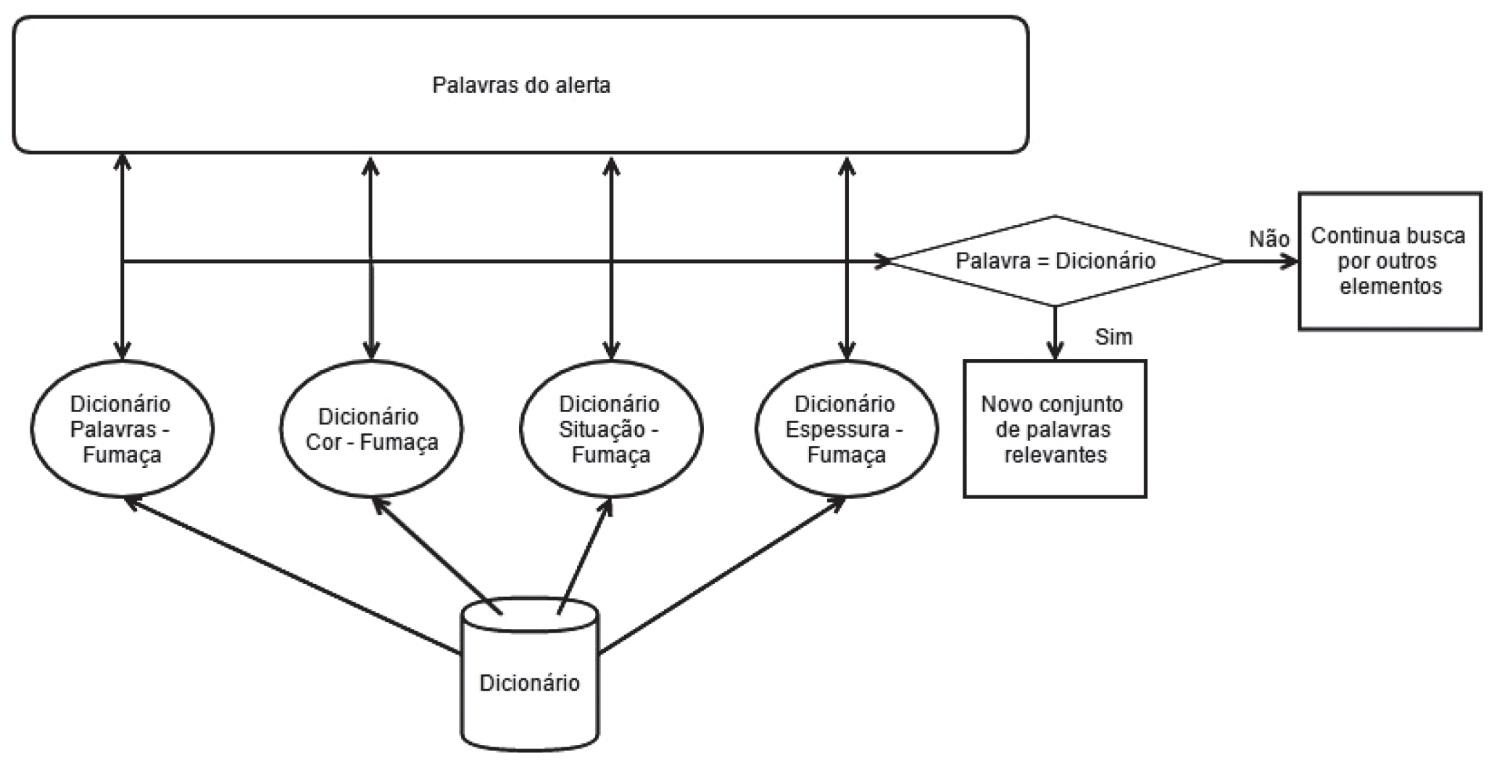

Fig. 19 - Fluxo do algoritmo - Encontrando palavras relevantes à fumaça.

Fig. 19 - Algorithm Flow - Finding words relevant to smoke. 


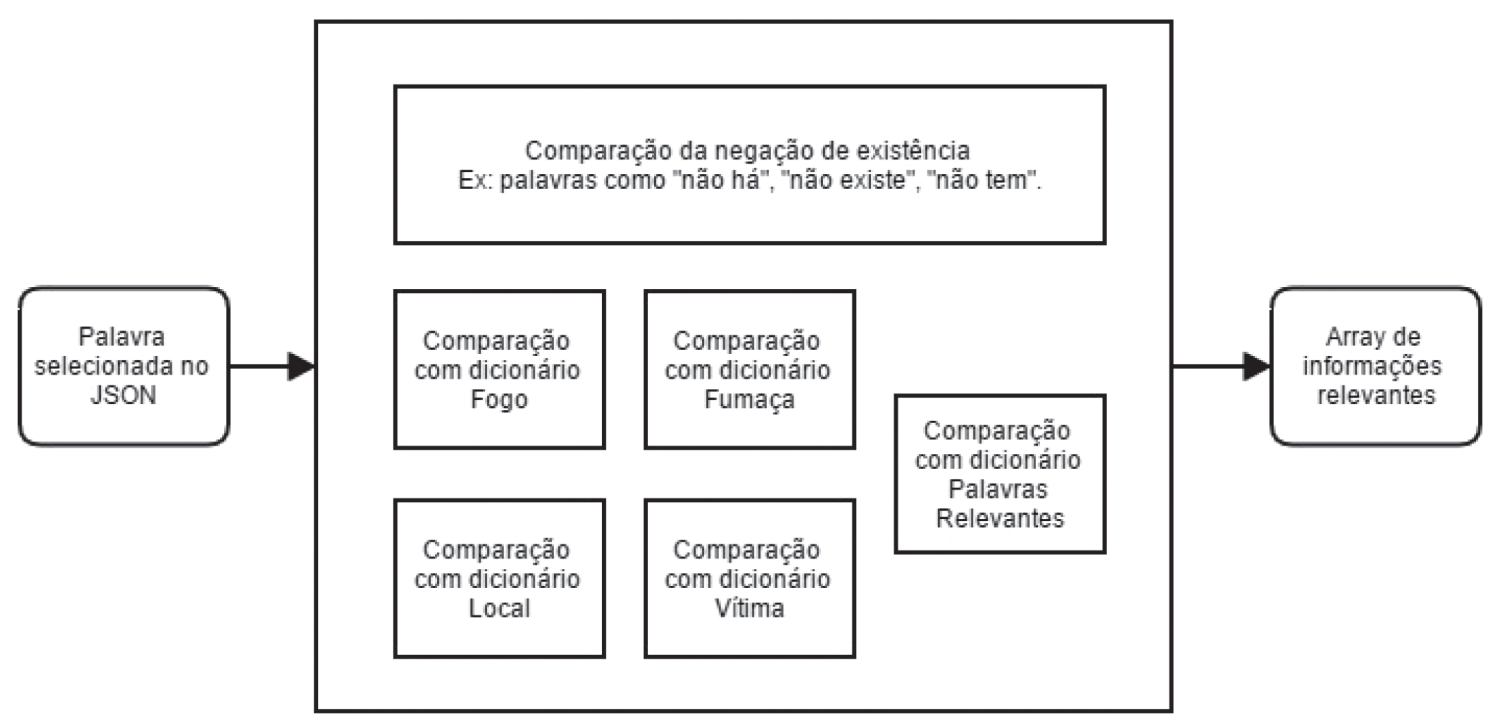

Fig. 20 - Processo de identificação da situação.

Fig. 20 - Situation identification process.

informações de ambos os alertas, gerando uma situação mais precisa e eficaz para a tomada de decisão dos operadores humanos. A fig. 21 mostra o fluxo desta fase do processo.

O procedimento acima foi feito com os JSONs criados pela biblioteca Cogroo, tendo como origem o texto de três alertas de incêndio que contendo informações relevantes sobre uma ocorrência, como a existência de fogo, a direção em que o mesmo ocorre, referências e local. Após a criação do JSON da biblioteca gramatical Cogroo de acordo com o texto enviado e a preparação dos dados de um alerta, temos a seguinte estrutura.

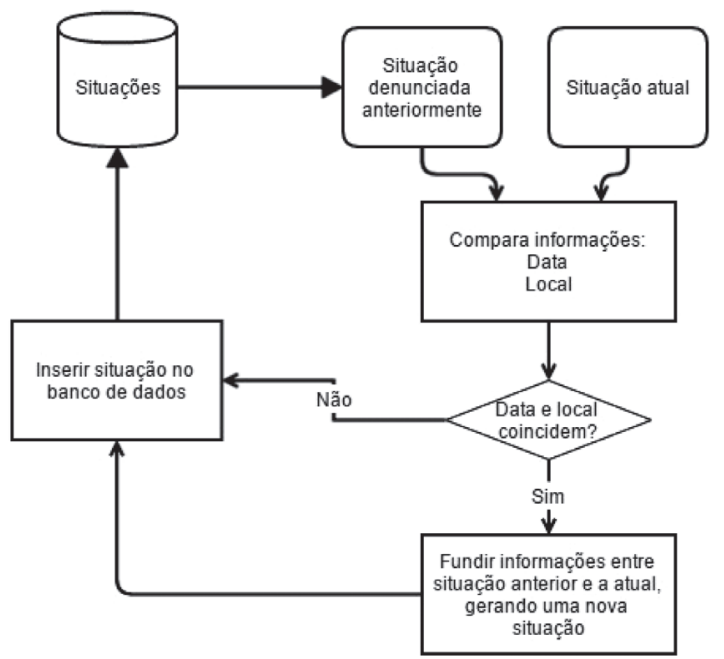

Fig. 21 - Fusão de situações.

Fig. 21 - Merging situations.
Como é visto na fig. 22, palavras relevantes foram categorizadas para a existência de fogo, fumaça, vítimas, informações sobre a localização do incêndio florestal e palavras relevantes ao contexto. Cada um trazia uma informação específica com características de fogo, fumaça e a consciência de que existe uma vítima, fazendo com que a fusão dos três criasse uma situação final mais precisa.

Após a criação da situação final com a fusão de dados que também foi inserida ao banco, utilizamos uma API para obter dados meteorológicos para criar ao menos uma hipótese do que acontecerá futuramente em dada situação. A API utilizada foi a do site https://www. wunderground.com/. Os dados meteorológicos mais importantes para este domínio, segundo integrantes do Corpo de Bombeiros, são:

a) Temperatura (graus Celsius);

b) Direção do vento;

c) Velocidade do vento (quilômetros por hora);

d) Umidade relativa do ar (porcentagem);

e) Ponto de orvalho (graus Célsius).

A justificativa da importância desses dados foi confirmada por um integrante do Corpo de Bombeiros, chefe da Brigada de Incêndio, identificando que os dados definidos acima são os que mais impactam na propagação do fogo. A aprovação de todos os integrantes será feita posteriormente. Análises científicas de longo prazo sobre o comportamento do fogo no Cerrado corroboram essa avaliação prática (IBAMA, 2010).

Com a obtenção dos dados meteorológicos, é verificado na situação resultante da fusão se existe fogo ou 


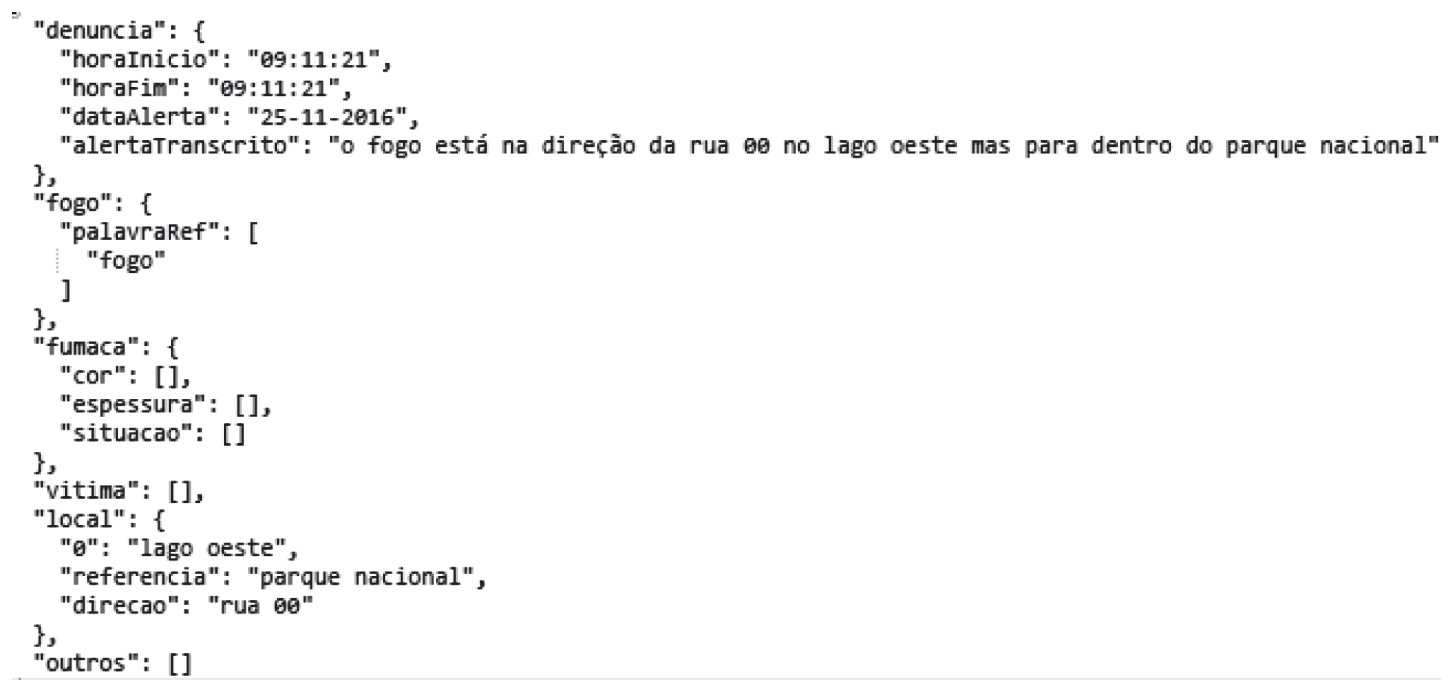

Fig. 22 - Exemplo da estrutura de dados provenientes de alerta.

Fig. 22 - Example of data structure sourced from warning.

fumaça. Caso positivo, será criada uma tabela de dados meteorológicos e um resultado do que poderá acontecer se mantidas essas condições, conforme ponderação a ser posteriormente instituída por corpo de especialistas.

Incêndios Florestais, incompletude de dados no DF e o sistema de alerta

A situação de um incêndio florestal, em 2016, atingindo o entorno do conjunto Mangueiral, pertencente a São Sebastião, planejado e recentemente inaugurado, às margens da DF001 e a leste da área de estudo, é uma clara demonstração das possiblidades de incremento desses quadros de risco no DF (Metrópoles, 2016; fig. 3). Está em questão a deflagração de incêndios nas áreas de matas nativas e a necessária revisão da configuração dos espaços de transição na ocupação territorial de contato entre zonas urbanas e Cerrado. Considerandose a multiplicidade e a convergência de fatores para a intensificação de ocorrências críticas, não se coloca isoladamente a prerrogativa do ordenamento territorial na redução de riscos, mas a pertinência de avaliação continuada das condições de vulnerabilidades locais, da crítica às diretrizes e às práticas de gestão urbana, que dependem de dados e informações estruturadas disponíveis (S. Cutter, 2011).

A incompletude de dados estruturados tem efeitos práticos na gestão de situações críticas. A imagem de área afetada por incêndio florestal na EEJBB, no ano de 2011, que pertence ao acervo histórico da unidade, pode traduzir como registro imagético a intensidade do fogo e parte de suas características. O registro, datado de 15 de setembro de 2011, permite indicar que ocorreu incêndio de copa, mas não temos a especificação de sua localização, dado relevante para a análise dos efeitos futuros sobre a paisagem e para o planejamento de ações. Algo que a notificação do sistema de alerta pode introduzir nas práticas de monitoramento local (fig. 23).

O comportamento do fogo em queimadas do Cerrado depende do tipo de fitofisionomia e da carga de combustível, associada à periodicidade de queima, além dos fatores climáticos já tratados. O reconhecimento paisagístico dos remanescentes de Cerrado e de sua diversidade é um componente relevante para a preservação das áreas representativas do bioma em situação urbana. $\mathrm{A}$ interlocução com a sociedade, associada aos dispositivos tecnológicos do projeto, pode introduzir novos parâmetros e práticas de observação dos efeitos do fogo sobre essas paisagens, considerando o médio e o longo prazo. A relevância do sistema de alerta, como base estruturada de dados, que permitirá ampliar o conhecimento das dinâmicas dos incêndios florestais no DF, pode ser apreendida no histórico das ocorrências. Os dois maiores incêndios registrados sobre a EEJBB têm intervalo de seis anos, 2005-2011, sobre os quais não temos outros registros, exceto os dados da base de queimadas do INPE.

\section{Conclusão}

O problema da recorrência de incêndios florestais no DF, atingindo áreas protegidas de Cerrado, deixa em aberto o quadro de dificuldades da gestão local quanto às zonas territoriais de contato entre o urbano e o Cerrado. O alcance dos serviços nacionais e seus propósitos de disponibilidade ou armazenamento de dados, embora úteis para a construção de análises indicativas das recorrências, não se integram a bases locais com a mensuração e descrição dos incêndios florestais e seus contextos espaciais, de forma a repercutir em políticas de ordenamento territorial. E quando esse propósito existe, como no caso do PREVFOGO 


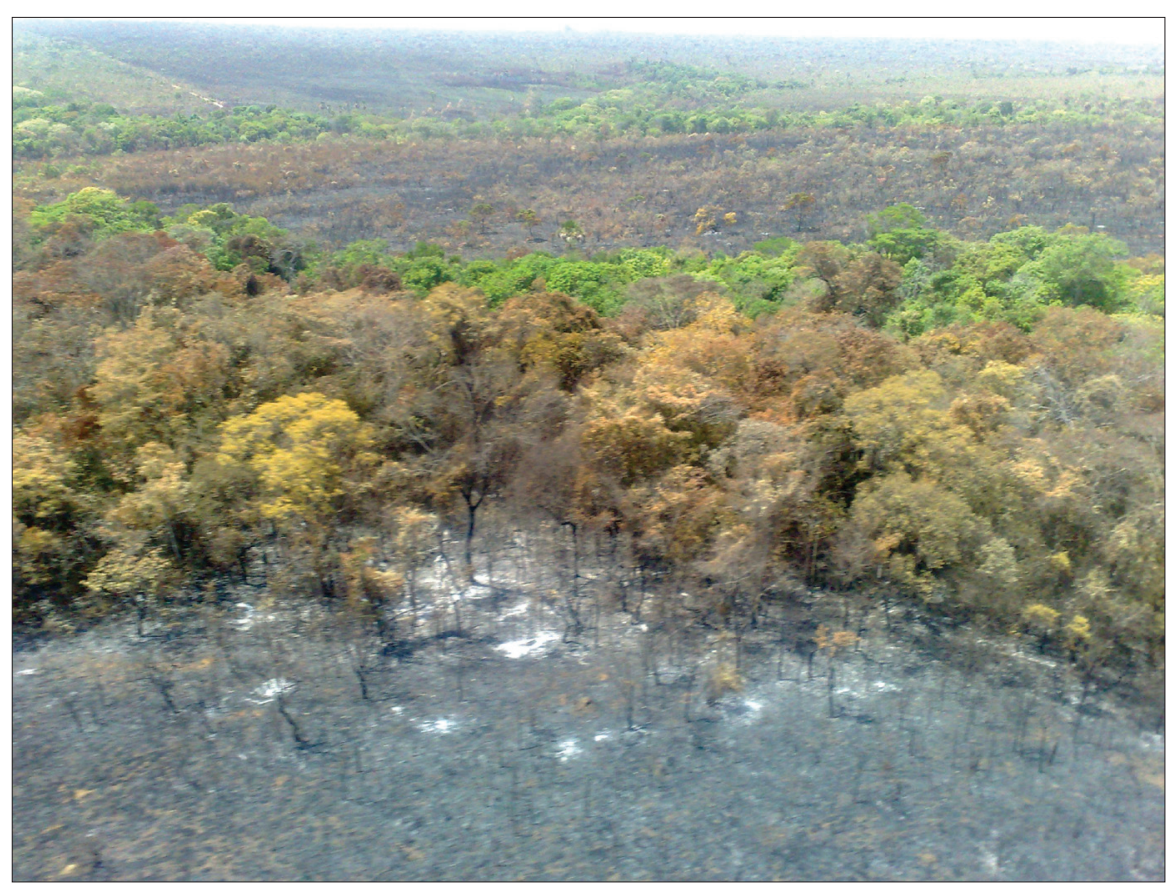

Fig. 23 - Área queimada da Estação Ecológica - 15/09/2011.

Fig. 23 - Burned area from Ecologic Station - 15/09/2011.

do Ministério do Meio Ambiente, o repertório de séries de dados é restrito, tendo em conta as razões já explicitadas de baixa disponibilidade de recursos humanos para a coleta, sistematização e análise de dados associados às ocorrências no DF.

A valorização das instâncias locais, em acordos de âmbito internacional, para a prevenção de situações de desastres está sendo enfatizada. O Marco de Sendai, de 2015, do qual o Brasil é signatário, traduz esse enfoque (UN, 2015). Da perspectiva das condições anteriormente relatadas e considerando a insuficiência dos serviços nacionais e locais de informação, a investigação até aqui realizada visa integrar estratégias de prevenção à participação da sociedade local.

Os dados públicos disponíveis para observação do quadro dos incêndios florestais no DF foram explorados quantitativa e temporalmente para corroborar a análise da recorrência no contexto de contato urbano e áreas protegidas de Cerrado, mas também para instruir propósitos relacionados à estruturação e utilização do sistema de alerta e sua potencial incorporação à gestão local. Nesse sentido, reconhece-se o caráter de complementaridade do projeto em relação aos serviços disponíveis, com envolvimento colaborativo da sociedade local na produção de dados via aplicativos móveis, de um lado, e, de outro, no âmbito da informação e do conhecimento sobre incêndios florestais, introduzir um meio inteligente de comunicação e de gestão de situações críticas, em Brasília, DF, mas com possibilidade de adequação a outros contextos.

\section{Instituições participantes do DF100Fogo}

Instituto Brasileiro de Informação em Ciência e Tecnologia - IBICT; Universidade Federal de São Carlos- UFSCar; Jardim Botânico de Brasília - JBB e Centro Universitário Eurípedes de Marília - UNIVEM.

\section{Referências Bibliográficas}

Ab’sáber, A. (2003). Os domínios de natureza no Brasil: potencialidades paisagísticas, Ateliê Editorial, São Paulo.

Correa, S. de C. (2007). A influência de sistemas climáticos sobre os incêndios florestais - estudo de caso: evento de incêndio ocorrido em setembro de 2005 no Jardim Botânico de Brasília (Master dissertation). Universidade de Brasília, Brasília, 70 p.

Cutter, S. L. (2011). A ciência da vulnerabilidade: modelos, métodos e indicadores. Ferreira, Victor (tradutor). Revista Crítica de Ciências Sociais [online], $\mathrm{n}^{\circ}$ 93, Coimbra, 59-69.

DISTRITO FEDERAL. JARDIMBOTÂNICO DE BRASÍLIA(2011). Relatório de atividades de 2011, JBB, Brasília. Disponível: http://www.jardimbotanico.df.gov.br [26/04/2017]

DISTRITO FEDERAL. JARDIM BOTÂNICO DE BRASÍLIA (2010). Resumo Executivo do Plano de manejo. [En línea], JBB, Brasília. Disponível:

http://www.jardimbotanico.df.gov.br [07 de março de 2014]. 
DISTRITO FEDERAL. Decreto $\mathrm{n}^{\circ} 17.431$, de 11 de junho de 1996. Institui o Plano de Prevenção e Combate a Incêndios Florestais do Distrito Federal. DODF, de 12 de junho de 1996. Disponível: http://www. sinj.df.gov.br/SINJ/BaixarArquivoNorma.aspx?id_ norma $=30044$ [08 $-11-2016]$

DISTRITO FEDERAL (Brasil). Instituto do Meio Ambiente e dos Recursos Hídricos (2016 a). Gerência de Emergências e Riscos Ambientais. Relatório de área queimada nos parques e unidades de conservação do Distrito Federal no ano de 2015. IBRAM, Brasília, DF. 144 p.

DISTRITO FEDERAL (Brasil) (2016 b). Decreto n. ${ }^{\circ} 37.549$, de 15 de agosto de 2016. Institui o Sistema Distrital de Prevenção e Combate aos Incêndios Florestais. DODF. Seção I, 2, de 16 de agosto de 2016.

DISTRITO FEDERAL (2015). Mapa de Risco ecológico de perda de áreas remanescentes do Cerrado Nativo. ZEE. MAPA 8, ANEXO I. Disponível: http://www.zee. df.gov.br/images/Mapas\%20de\%20risco/4-\%20risco_ cerrado_2015.jpg [04 - 11-16]

Eiten, G. (1977). Delimitação do conceito de cerrado. Arquivos do Jardim Botânico do Rio de Janeiro. Vol. XX1, Rio de Janeiro, 125-134.

Haklay, M. (2013). Citizen Science and Policy: A European Perspective. Case studies. Vol 4. Washington, DC. Woodrow Wilson International Center for Scholars, 2015. Disponível: https://www.wilsoncenter. org/sites/default/files/Citizen_Science_Policy_ European_Perspective_Haklay.pdf [11 -11- 2015].

IBAMA (2010). Efeitos do regime de fogo sobre a estrutura de comunidades do Cerrado: projeto fogo. Heloisa Sinátora Miranda (org). Ibama, Brasília. 144 p. Disponível: http://www.ibama.gov.br/sophia/cnia/ livros/efeitosdoregimedofogodigital.pdf [05-05-17].

IBAMA. Prevfogo. Disponível: http://siscom.ibama.gov. br/sisfogo/publico.php [11- 04-16].

INMET (s.d). Normais climatológicas - 1961 - 1990 (versão digital, revista e ampliada), INMET, Brasília. Disponível: http://www.inmet.gov.br/portal/index. php? $r=c l i m a /$ normaisClimatologicas [25-04-17]

INPE (2017). Programa Queimadas. Disponível: https:// queimadas.dgi.inpe.br/queimadas [02-05-17].

INPE (2016). Programa Queimadas. Disponível: https:// queimadas.dgi.inpe.br/queimadas [17-02-16].

Kobiyama, M. (2006). Prevenção de desastres naturais: conceitos básicos, Editora Organic Trading, Curitiba, 109 p. Disponível: http://aguassubterraneas.cetesb. sp.gov.br/wp-content/uploads/sites/28/2014/05/ prevencaodedesastresnaturaisconceitosbasicos.pdf [23-11-2016].
Medeiros, M. B. de Miranda, H. S. (2005). Mortalidade pós-fogo em espécies lenhosas de campo sujo submetido a três queimadas prescritas anuais. Acta Botânica Brasileira, $n^{\circ}$ 19(3), 493-500. Disponível: www.scielo.br/pdf/abb/v19n3/27363.pdf [24-08-16].

METRÓPOLES (2016). Bombeiros combatem incêndios no DF (2016- 07- 24), Metrópoles, [eletrônico]. Disponível: www.metropoles.com, Distrito Federal. [27-01-2017].

Pascoalino, A., Almeida, L. Q. de. (2014). Desastres naturais e gestão de risco no Brasil: características e contributos para o ordenamento territorial. Multidimensão e Territórios de Risco. Imprensa da Universidade de Coimbra; RISCOS - Associação Portuguesa de Riscos, Prevenção e Segurança, Coimbra. Disponível: https://digitalis.uc.pt/pt-pt/ node/106201?hdl=34933 [10-11-2016].

Pereira Junior, A. da C. (2003). Métodos de geoprocessamento na avaliação sustentabilidade do Cerrado ao fogo (Doctoral dissertation). UFSCar, São Carlos, 97 p.

Silva, D. M., Loiola, P. D. P., Rosatti, N. B., Silva, I. A., Cianciaruso, M. V., \& Batalha, M. A. (2011). Os efeitos dos Regimes de Fogo sobre a Vegetação de Cerrado no Parque nacional das Emas, GO: Considerações para a Conservação da Diversidade. Biodiversidade Brasileira, vol. $1 / \mathrm{n}^{\circ} 2$, Instituto Chico Mendes de Conservação da Biodiversidade, 26-39.

SEDHAB. Mapa Índice - Articulação SICAD, Escala 1:10.000 e 1:2.000. http://www.sedhab.df.gov.br/mapas_ sicad/index2.htm [En línea]. SEDHAB, Brasília, [10-11-2014].

Sieber, R. E., Haklay, M. (2015). The epistemology(s) of volunteered geographic information: a critique. Geo - geography and environment, vol. 2, 122-136. DOI: https://doi.org/10.1002/geo2.10 [17-04 -2017]

Tavares, M. de F. D., Nakagomi, B. (2016). Brasília: utopia urbana e a desconstrução da paisagem idealizada. Actas do XIV Coloquio Interanacional de Geocrítica.

UFSC. CEPED. Atlas Brasileiro de Desastres Naturais - 1991 - 2012. Vol. Goiás e DF. Florianópolis: CEPED/UFSC, 2013. ( $2^{\mathrm{a}}$ edição revisada). Disponível:

htps://s2id.integração.gov.br [16-11- 2016].

UNITED NATIONS (2015). Sendai Framework for Disaster Risk Reduction 2015-2030. Disponível: http://www. unisdr.org/files/43291_sendaiframeworkfordrren. pdf [14-11-16].

Walter, B. M. T. (2006). Fitofisionomias do bioma cerrado: síntese terminológica e relações florísticas (Tese). UnB, Brasília. 